\title{
The Las Matras tonalitic-trondhjemitic pluton, central Argentina: Grenvillian-age constraints, geochemical characteristics, and regional implications
}

\author{
A.M. Sato ${ }^{\mathrm{a}, *}$, H. Tickyj ${ }^{\mathrm{b}}$, E.J. Llambías ${ }^{\mathrm{a}}$, K. Sato ${ }^{\mathrm{c}}$ \\ ${ }^{a}$ Centro de Investigaciones Geológicas, CONICET, Universidad Nacional de La Plata, Calle 1 No 644, La Plata, Pcia BsAs 1900, Argentina \\ ${ }^{\mathrm{b}}$ CONICET, Universidad Nacional de La Pampa, Av. Uruguay 151, Santa Rosa, La Pampa 6300, Argentina \\ ${ }^{\mathrm{c}}$ CPGeo, Instituto de Geociências, Universidade de São Paulo, CP 11348, São Paulo SP 05422-970, Brazil
}

Received 1 March 1999; received revised form 1 December 1999; accepted 1 April 2000

\begin{abstract}
The N-S trending belt with Grenvillian-age rocks developed in central western Argentina represents the basement of an allochthonous terrane derived from Laurentia during the Early Paleozoic. The Las Matras pluton $\left(36^{\circ} 46^{\prime} \mathrm{S}, 67^{\circ} 07^{\prime} \mathrm{W}\right)$ is located at the southern extension of this belt in the Las Matras Block. It consists of a low-Al tonalitic to trondhjemitic facies characteristic of an arc magmatism. Isotopic studies yielded Grenvillian $\mathrm{Rb}-\mathrm{Sr}(1212 \pm 47 \mathrm{Ma})$ and $\mathrm{Sm}-\mathrm{Nd}(1188 \pm 47 \mathrm{Ma})$ ages which, due to the undeformed and non-metamorphosed character of the pluton, are interpreted to represent a crystallization age of around $1200 \mathrm{Ma}$. Although this age is slightly older than available dates from other exposures of the same belt, and the undeformed feature is also distinctive for Las Matras, the depleted Sr and Nd isotopic signatures of the pluton agree with those from other magmatic rocks involved in that belt. The differences found between Las Matras and the northern exposures indicate that this belt with Grenvillian-age rocks comprises regions of non-homogeneous evolution. Although the correlation of the Lower Paleozoic platform carbonates from the sedimentary cover of the Grenvillian-age basement rocks suggests the surroundings of the Southern Grenville Province (Texas and northern Mexico) as the probable detachment site for the Argentine belt, comparison of magmatic and tectonic processes involved in these basement rocks does not indicate similar evolutions. This fact can suggest an independent evolution of the Argentine belt prior to amalgamation to the Laurentian Grenville orogen. (C) 2000 Elsevier Science Ltd. All rights reserved.
\end{abstract}

Keywords: Grenville orogeny; Central and western Argentina; Trondhjemites; Terrane accretion

\section{Introduction}

The main orogenic activities in the crystalline basement of central and western Argentina (Fig. 1) took place during latest Proterozoic to Early Paleozoic times (Pampean and Famatinian orogenic cycles of the Proto-Andean southwestern margin of Gondwana). However, older rocks of Mesoproterozoic Grenvillian ages have also been identified within this orogen. These older rocks were first documented by Varela and Dalla Salda (1992; Rb-Sr data) at Sierra de Pie de Palo, Western Sierras Pampeanas. After that, metamorphic rocks of similar ages $(\mathrm{U}-\mathrm{Pb}, \mathrm{Sm}-\mathrm{Nd}, \mathrm{Rb}-\mathrm{Sr})$ were successively found in a N-S belt comprising the Precordillera (Abruzzi et al., 1993; Mahlburg Kay et al., 1996), Western Sierras Pampeanas (McDonough et al., 1993; Ramos et al., 1996; Varela et al., 1996; Pankhurst and

\footnotetext{
* Corresponding author. Tel.: +54-221-425-8696; fax: +54-221-4215677.

E-mail address: sato@cig.museo.unlp.edu.ar (A.M. Sato).
}

Rapela, 1998), Cordillera Frontal (Ramos and Basei, 1997; Basei et al., 1998), and San Rafael Block (Astini et al., 1996; Cingolani and Varela, 1999). Recently, the first results of $\mathrm{Rb}-\mathrm{Sr}$ and $\mathrm{Sm}-\mathrm{Nd}$ Mesoproterozoic ages were reported by Sato et al. $(1998,1999)$ for a tonalitic to trondhjemitic pluton at Las Matras in the La Pampa Province of central Argentina. This pluton is located just at the southern extension of this $\mathrm{N}-\mathrm{S}$ belt. It seems to belong to the same tectonic unit, although some geological features are different, like those concerning the visible lack of ductile deformation. To the east of this almost $900-\mathrm{km}$-long belt with Grenvillian-age rocks, a parallel belt comprises the Eastern Sierras Pampeanas and the Chadileuvú Block, in which the Lower Paleozoic Famatinian tectonic, metamorphic, and igneous activities are the most important features.

The Grenvillian-age rocks of central and western Argentina have been involved in the basement of Laurentian-derived exotic terrane proposals. These terranes should have docked to the southwestern margin of Gondwana during the Early Paleozoic Famatinian orogeny; they have 
been called "Occidentalia" (Dalla Salda et al., 1992a,b, 1998; Dalziel et al., 1994), "Precordillera" (Astini et al., 1995, 1996; Astini, 1998; Rapela et al., 1998a), "Cuyania" (Ramos, 1995; Ramos et al., 1996, 1998), "Texas plateau" (Dalziel, 1997), and "Chilenia" (Ramos et al., 1984). These various proposals do not coincide in their terrane extensions, and they are based on the following tectonic hypothesis: a large part of Laurentia was left behind after a continent-continent collision (Occidentalia), an independant smaller block separated from Laurentia and collided with Gondwana (Precordillera and Cuyania), and a part of a continental plateau located adjacent to Laurentia was left after a collision against Gondwana (Texas plateau). Chilenia has been proposed as another smaller block docked later during the Early Paleozoic. The most characteristic rocks of these terranes, especially those of the Precordillera and Cuyania terrane, are Grenvillian-age basement rocks and a sedimentary cover. The similarity in isotopic signatures of these basement rocks and those of the North American Grenville Province was pointed out by Mahlburg Kay et al. (1996). Among the cover rocks, the most characteristic are the Lower Paleozoic platform carbonate deposits of the Precordillera, whose fossiliferous content, stratigraphy, and paleomagnetic data are comparable to those of the Appalachian equivalent strata (Bond et al., 1984; Astini et al., 1995; Thomas and Astini, 1996; 1999; Astini, 1998; Benedetto, 1998; Keller et al., 1998; Rapalini and Astini, 1998). These comparisons include the possibilities that the North American Appalachian orogeny and the South American Famatinian orogeny initiated as a single complex mountain system (Dalla Salda et al., 1992b; Dalziel et al., 1994) or developed in close proximity (Dalziel, 1997).

It is beyond the scope of this paper to discuss the validity of the different tectonic hypotheses and the precise limits of each proposed terrane. Here, we compare our data on the Las Matras area with all the Grenvillian-age rocks of central and western Argentina and include all of them within the term "belt with Grenvillian-age rocks."

The $\mathrm{Rb}-\mathrm{Sr}, \mathrm{Sm}-\mathrm{Nd}$, and $\mathrm{K}-\mathrm{Ar}$ ages obtained from the Las Matras pluton as well as their geological and geochemical features are reported in this paper. They are the first indications that the belt with Grenvillian-age rocks of central and western Argentina extends up to latitudes close to $37^{\circ} \mathrm{S}$. Hence, they contribute to our knowledge of the geology of this Mesoproterozoic basement belt and to the geotectonic framework related to the LaurentiaGondwana interaction.

\section{Geological setting}

The Las Matras pluton $\left(36^{\circ} 46^{\prime} \mathrm{S}, 67^{\circ} 07^{\prime} \mathrm{W}\right)$ is located in the northwestern part of La Pampa Province (Fig. 1). After a brief reference in accord with an unpublished report of Ortiz (1967), Llambías (1975) and Linares et al. (1980) described a dioritic pluton of Late Proterozoic age, intruded by a
Paleozoic granite. The dates obtained by the latter authors were in the range $810-690 \mathrm{Ma}(\mathrm{K}-\mathrm{Ar}$ in amphiboles and whole-rock) for the basic facies and 392-382 Ma (K-Ar whole-rock) for the acidic facies.

Younger rock units include Upper Cambrian-Lower Ordovician (Melchor et al., 1999a,c) limestones and marbles (San Jorge Formation: Criado Roqué, 1972) (?)Upper Carboniferous quartzites (Agua Escondida Formation: González Díaz and García, 1968) and Permo-Triassic volcanic rocks (Linares et al., 1980). The rock association of this region of La Pampa Province is similar to that of the San Rafael Block to the northwest (Fig. 1), and for this reason we propose the new name "Las Matras Block" (Fig. 1). This block is in contrast with southeastern La Pampa Province where the (?)Upper Cambrian to Ordovician metamorphic rocks and Upper Cambrian to Devonian granitoids are the most important units underlying the Permo-Triassic volcanics (Linares et al., 1980; Sato et al., 1996; Tickyj et al., 1999b). Based on this latter rock association, the southeastern region of La Pampa Province was termed the Chadileuvú Block (Fig. 1) by Llambías and Caminos (1987) and Llambías et al. (1996).

The limestones of the San Jorge Formation and the quartzites of the Agua Escondida Formation crop out in close spatial association within the Las Matras Block, although the stratigraphic relationship between them is not yet clear. The recently obtained deposition age of the San Jorge Formation (Melchor et al., 1999a) indicates it is coeval with the Cambro-Ordovician carbonates of the Precordillera and San Rafael Block, which have Laurentian affinities. The possibility remains open that the quartzites exposed in the area of Las Matras - although assigned to the Late Carboniferous Agua Escondida Formation by Linares et al. (1980) - can also be correlated with the clastic facies of those carbonate shelf deposits extending from the Precordillera.

The Las Matras pluton appears without exposed country rock relationship. The nearest metamorphic rocks recognized are those in a well $280 \mathrm{~m}$ in the underground of the "Subcuenca de Alvear," $70 \mathrm{~km}$ north of Las Matras. They are garnet-hornblende-biotite-schists, with one $\mathrm{K}-\mathrm{Ar}$ determination of $605 \mathrm{Ma}$ (Criado Roqué, 1979). Based on their lithology and age, Criado Roqué (1979) correlated these rocks with the Cerro Ventana Formation (Criado Roqué, 1972), the metamorphic basement of the San Rafael Block. Criado Roqué (1979) also mentioned the possibility of correlation with the Las Matras pluton, based on preliminary $\mathrm{K}-\mathrm{Ar}$ ages of this pluton published later by Linares et al. (1980). The Grenvillian age of the Cerro Ventana Formation was later confirmed by $\mathrm{U}-\mathrm{Pb}$ and $\mathrm{Rb}-\mathrm{Sr}$ methods (Astini et al., 1996; Cingolani and Varela, 1999).

Metamorphic rocks are found in the Chadileuvú Block, $150 \mathrm{~km}$ southeast of Las Matras (Linares et al., 1980; Tickyj, 1999). There, the metamorphism took place during (?) latest Precambrian to Early Paleozoic times. Within the Chadileuvú Block, metamorphic rocks are described, 


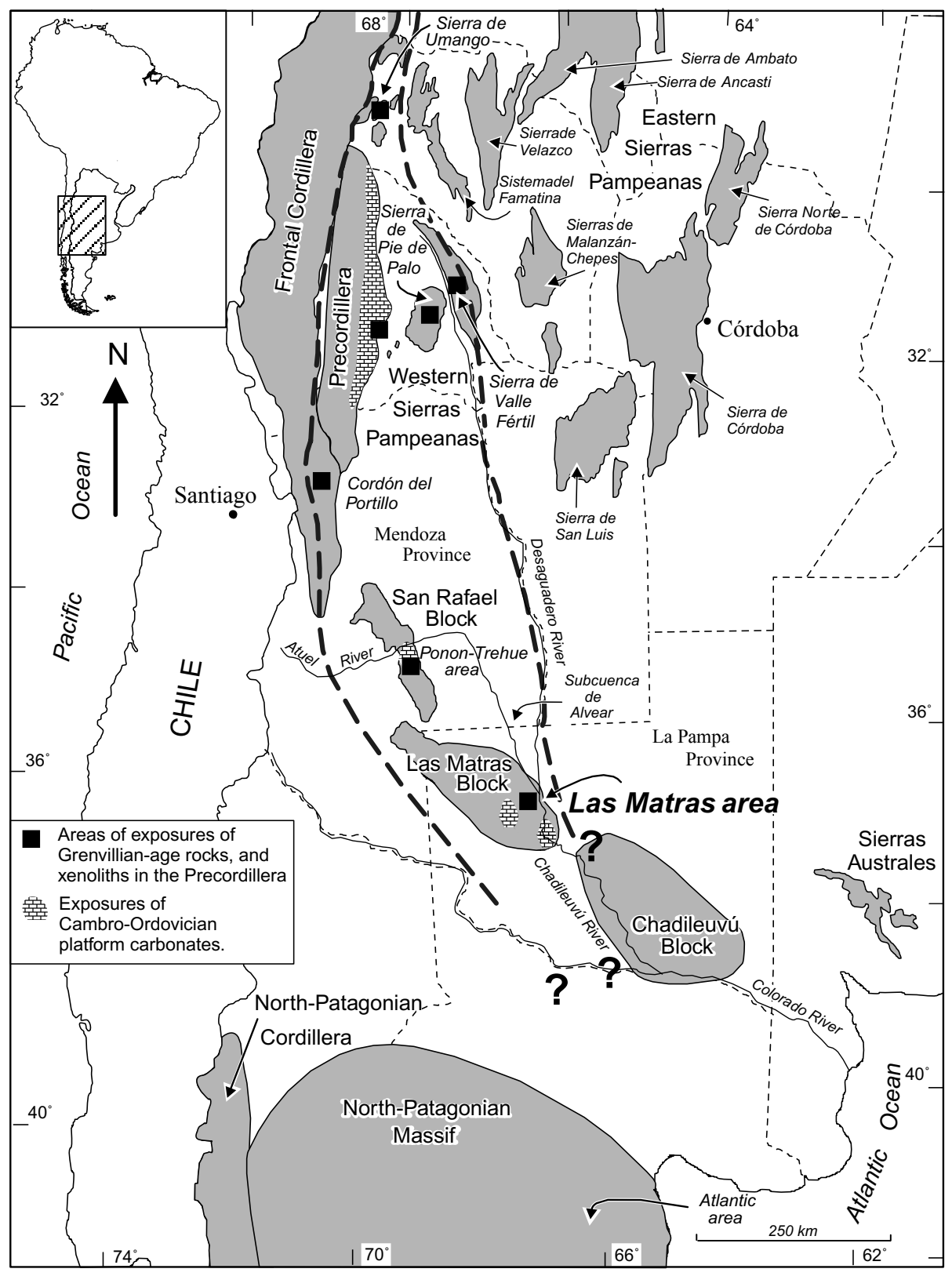

Fig. 1. The Proterozoic and Paleozoic geological units of central and western Argentina. The areas with Grenvillian-age rock exposures (Western Sierras Pampeanas, Precordillera, Frontal Cordillera, San Rafael Block, and Las Matras Block) are arranged in a N-S belt, defining a "belt with Grenvillian-age rocks." This belt does not mean a new terrane proposal, although the following proposed terranes are involved, with different areal extensions and paleotectonic hypotheses referring to a terrane of Laurentian origin: Occidentalia (Dalla Salda et al., 1992a), Precordillera (Astini et al., 1995), Cuyania (Ramos, 1995), Texas Plateau (Dalziel, 1997) and Chilenia (Ramos et al., 1984). Las Matras is located in the southern region of this belt (Las Matras Block). The Eastern Sierras Pampeanas and the Chadileuvú Block are located to the east of this belt, where the most important orogenic activities took place during the latest Proterozoic to Early Paleozoic times.

among others, in the area of Valle Daza, where a mafic granoblastic rock containing clinopyroxene, amphibole, quartz, plagioclase, and K-felspar was dated at $884 \mathrm{Ma}$ (K-Ar amphibole) by Linares et al. (1980).

In the area of Las Matras (Fig. 2) the poor exposures of the pluton are found in an area of $4 \times 4 \mathrm{~km}^{2}$ on very low and gentle slopes, covered by unconsolidated sediments and vegetation. The outcrops are mainly concentrated in the eastern part of the area depicted in Fig. 2. To the west, there are exposures of quartzite beds (Cerro El Poleo), where the general bedding trend is $\mathrm{N} 45^{\circ} \mathrm{W}$ and subvertical. The exposed sequence was characterized by Melchor (1996) as consisting of light gray fine quartz arenites, partially stained by reddish oxides, and scarce layers of conglomeradic arenites and fine-grained conglomerates. Tabular beds with parallel lamination predominate; occasional layers with cross-bedding were also found. Although very small outcrops of the Las Matras pluton are 


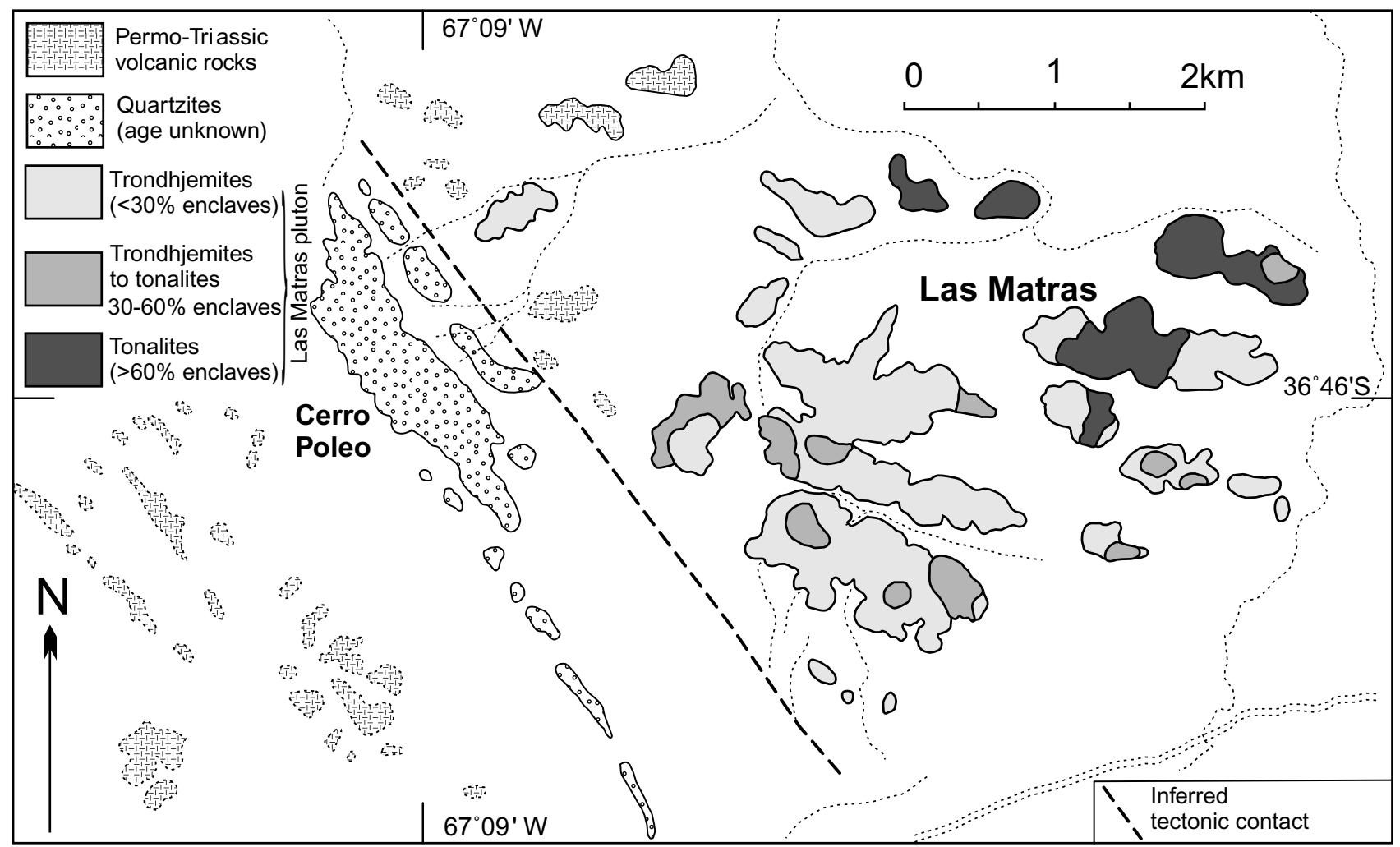

Fig. 2. Geological sketch map of the Las Matras pluton; for location see Fig. 1. The pluton is poorly exposed, without country rock relationship, and covered by modern sediments. The contacts between the internal facies (areas of different proportions of tonalitic enclaves) of the pluton are transitional.

found as close as $200 \mathrm{~m}$ from the quartzites, no contact could be found between them. The lack of metamorphism in the quartzites, plus the very sharp NW-trending borders of their outcrops parallel to bedding, are suggestive of a possible tectonic contact between these units.

On the other hand, this contact area is covered by regoliths of Permo-Triassic volcanic rocks of mainly dacitic to rhyolitic compositions. A NW-trending rhyolitic dike cuts across the trondhjemitic facies of the pluton. In one of the Permian dacitic exposures, a brittle shear deformation, causing a penetrative fracture cleavage, could be observed in a NW-SE trending belt that is a few hundred meters wide. Such a NW-striking structure is widespread in the La Pampa Province, controlling many large-scale structures throughout the Paleozoic era, like the orientation of the metamorphic rocks, elongation of the Permian sedimentary basin, and distribution of the Upper Paleozoic volcanic rocks. West of the quartzite beds there are also other very small outcrops and regoliths of similar porphyritic volcanic rocks and tuffs, following a similar NW trend of the exposures.

\section{The Las Matras pluton}

The Las Matras pluton is an undeformed microgranitoid enclave pluton that is composed of a medium-grained leuco- cratic facies containing various proportions of dark, finegrained equigranular to porphyritic microgranitoid enclaves. The leucocratic facies is of trondhjemitic composition (as determined chemically), and the mafic facies is tonalitic. Due to the irregular distribution of the enclaves and their swarms (areas that range from meters in width up to hundreds of meters wide; see Fig. 2), the various rock types were distinguished as trondhjemites $(<30 \%$ of tonalitic enclaves; see Fig. 3a), trondhjemites to tonalites (30$60 \%)$, and tonalites $(<60 \%$ or areas of more homogeneous tonalitic facies; see Fig. 3d). Rocks of trondhjemitic composition cover the major area of exposures.

The enclaves show different sizes and morphologies (Fig. $3 \mathrm{~b}$ and $\mathrm{c}$ ). Some are homogeneously globular, with subcircular plan view, up to $2 \mathrm{~m}$ in diameter. The contacts are sharp, without chilled margins. Others have irregular shapes, but generally with lobated or crenulated contacts, coexisting with those of different sizes. Discrete felsic halos less than $1 \mathrm{~cm}$ thick could also be observed. Within the areas more homogeneously trondhjemitic, the enclaves are scarce, less than $5 \mathrm{~cm}$ wide, and have diffuse contacts. Within areas more homogeneously tonalitic, the trondhjemitic magmas appear as straight veins, with matching walls, filling narrow sectors between angulose enclaves. In some cases, they fill lobate interstices between enclaves, having coarser grain sizes than those of the enclaves.

The texture of the rocks is granular, with minerals in 

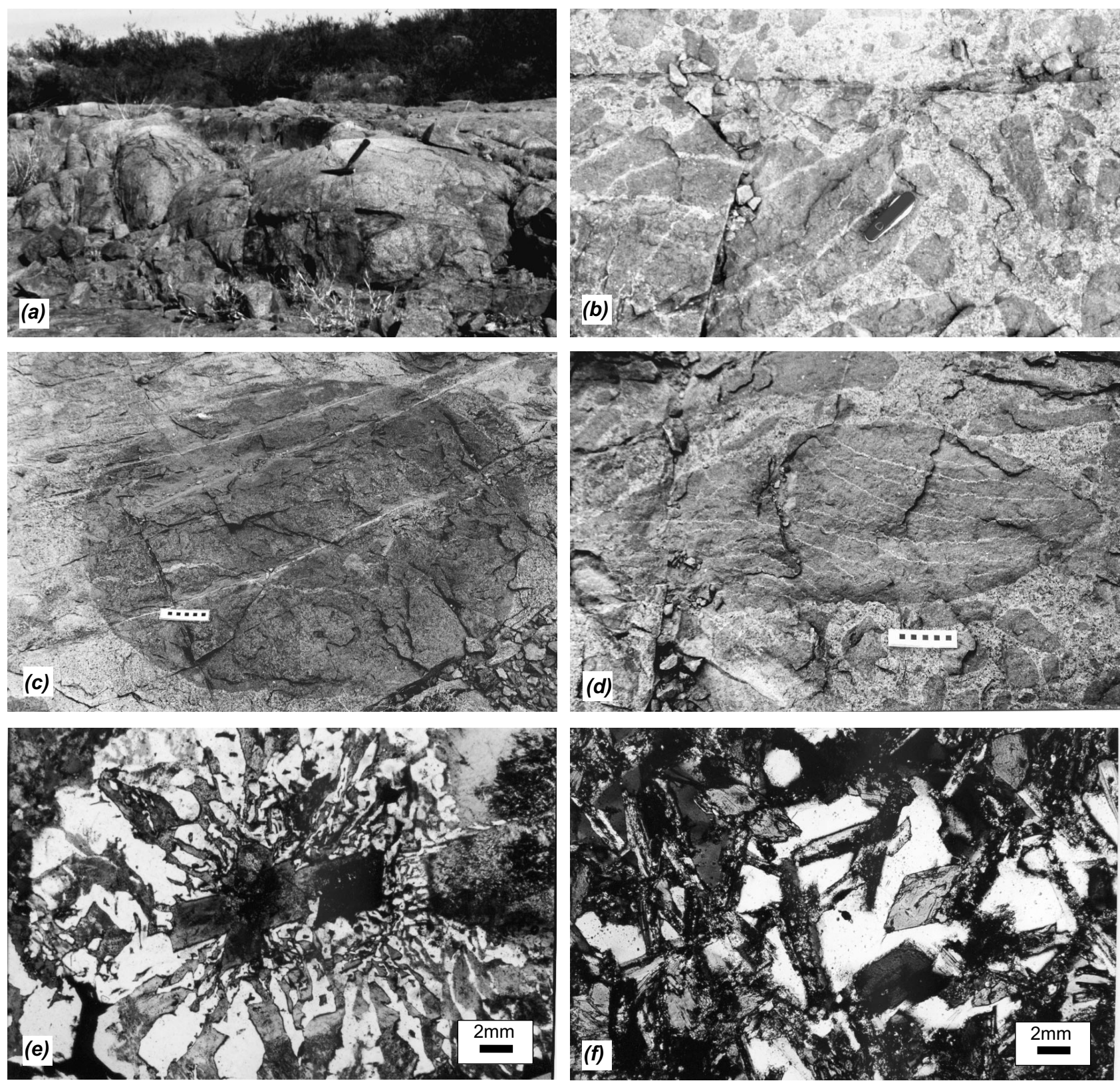

Fig. 3. (a) Las Matras pluton, a general field view of the homogeneous trondhjemitic facies in the central area of the pluton, almost without microgranitoid enclaves. (b, c, d) Different sizes and proportions of tonalitic enclaves in the eastern area of the pluton: (b) some have angular to lobular contours; (c) others have subcircular sections about $1 \mathrm{~m}$ in diameter (scale has $1 \mathrm{~cm}$ divisions); (d) tonalitic facies with abundant enclaves (scale has $1 \mathrm{~cm}$ divisions). Photomicrographs show unmodified magmatic textures; crossed polarizers: (e) trondhjemite with euhedral plagioclase surrounded by graphic intergrowth; (f) tonalite with quartz surrounding euhedral amphibole (central right), biotite, and plagioclase.

random orientations. Although 3D observations are difficult because of the poor exposures, mineral or enclave orientations due to magmatic flow or deformation processes, like those described by Vernon et al. (1988), could not be observed.

Geochemical and isotopic features (see below) suggest that the enclave facies is of cogenetic origin with the host rock. It was not possible to make geochemical or isotopic distinction between the two facies, like the case reported by Elburg and Nicolls (1995) and Elburg (1996) for the granitoids and volcanic rocks from the Lachlan Fold Belt.
There are occasional dikes, with different composition, cutting the pluton in different orientations. Their widths are less than $1 \mathrm{~m}$ and lengths less than $20 \mathrm{~m}$. The basic ones are dark, with afanitic texture, while the acidic ones are aplitic, pink-coloured, with diffuse and small enclaves.

The tonalitic rocks are composed of plagioclase, quartz, amphibole, biotite, and alkali feldspar, with opaque minerals, apatite, zircon, allanite, and sphene as accessory minerals, and scarce alteration to epidote and clorite. In the trondhjemitic facies, the alkali feldspar is more abundant, while amphibole is scarce or absent. The original magmatic 
Table 1

Major, trace and REE analyses from the Las Matras pluton and dikes

(Major oxides analyzed by fusion-ICP and trace and RE elements analyzed by fusion-ICP MS, at the Activation Laboratories (Canada). Standards used: STM1, MAG1, BIR1, DNC1, W2, MRG1, SY3, GXR1)

\begin{tabular}{|c|c|c|c|c|c|c|c|c|}
\hline & \multicolumn{8}{|c|}{ Trondhjemites } \\
\hline & LMT-7 & LMT-8 & LMT-9 & LMT-11 & LMT-14 & LMT-15 & LMT-22 & LMT-31 \\
\hline $\mathrm{SiO}_{2}$ & 70.67 & 71.54 & 73.32 & 72.09 & 71.74 & 75.09 & 75.51 & 71.59 \\
\hline $\mathrm{Al}_{2} \mathrm{O}_{3}$ & 13.41 & 14.25 & 13.67 & 13.05 & 13.27 & 13.21 & 12.59 & 13.75 \\
\hline $\mathrm{Fe}_{2} \mathrm{O}_{3}^{*}$ & 3.07 & 3.62 & 2.85 & 2.87 & 2.91 & 2.44 & 2.41 & 3.07 \\
\hline $\mathrm{MnO}$ & 0.08 & 0.07 & 0.04 & 0.06 & 0.05 & 0.05 & 0.06 & 0.04 \\
\hline $\mathrm{MgO}$ & 0.65 & 0.68 & 0.43 & 0.44 & 0.57 & 0.39 & 0.23 & 0.46 \\
\hline $\mathrm{CaO}$ & 2.17 & 2.30 & 2.38 & 2.00 & 2.15 & 1.62 & 1.38 & 2.07 \\
\hline $\mathrm{Na}_{2} \mathrm{O}$ & 4.03 & 4.16 & 4.11 & 4.22 & 4.02 & 4.00 & 4.52 & 4.02 \\
\hline $\mathrm{K}_{2} \mathrm{O}$ & 2.61 & 2.69 & 2.40 & 2.58 & 2.61 & 2.96 & 2.36 & 2.85 \\
\hline $\mathrm{TiO}_{2}$ & 0.33 & 0.36 & 0.31 & 0.29 & 0.32 & 0.25 & 0.23 & 0.30 \\
\hline $\mathrm{P}_{2} \mathrm{O}_{5}$ & 0.06 & 0.10 & 0.08 & 0.14 & 0.06 & 0.06 & 0.05 & 0.10 \\
\hline LOI & 0.92 & 0.95 & 0.77 & 0.83 & 1.00 & 0.89 & 0.70 & 0.95 \\
\hline Total & 98.00 & 100.72 & 100.34 & 98.57 & 98.70 & 100.96 & 100.03 & 99.17 \\
\hline $\mathrm{Rb}$ & 67 & 84 & 44 & 47 & 56 & 78 & 51 & 53 \\
\hline $\mathrm{Sr}$ & 210 & 237 & 256 & 197 & 215 & 171 & 152 & 213 \\
\hline $\mathrm{Y}$ & 33 & 32 & 19 & 33 & 28 & 32 & 37 & 33 \\
\hline $\mathrm{Zr}$ & 189 & 177 & 165 & 194 & 191 & 169 & 209 & 212 \\
\hline $\mathrm{Nb}$ & 9 & 9 & 6 & 8 & 8 & 9 & 4 & 7 \\
\hline $\mathrm{Ba}$ & 820 & 817 & 941 & 799 & 922 & 849 & 846 & 944 \\
\hline Cs & 1.9 & 3.4 & & 0.7 & 1.6 & 1.7 & & 0.8 \\
\hline Hf & 5.1 & 6 & & 5.3 & 5.1 & 5.8 & & 5.5 \\
\hline $\mathrm{Ta}$ & 2.58 & 2.47 & & 2.77 & 2.63 & 2.65 & & 2.5 \\
\hline $\mathrm{Tl}$ & 0.42 & 0.49 & & 0.17 & 0.21 & 0.48 & & 0.37 \\
\hline Th & 5.3 & 4.8 & & 5.2 & 5.3 & 5.3 & & 4.0 \\
\hline $\mathrm{U}$ & 1.5 & 1.7 & & 1.6 & 1.8 & 1.8 & & 1.4 \\
\hline $\mathrm{La}$ & 23.4 & 26.5 & & 27.8 & 22.6 & 27.4 & & 23.5 \\
\hline $\mathrm{Ce}$ & 51.5 & 56.4 & & 56.9 & 48.9 & 58.1 & & 51.4 \\
\hline $\operatorname{Pr}$ & 5.702 & 6.633 & & 5.946 & 5.332 & 6.724 & & 5.95 \\
\hline $\mathrm{Nd}$ & 24.2 & 30.4 & & 25.6 & 22.5 & 30.4 & & 24.1 \\
\hline $\mathrm{Sm}$ & 5.15 & 6.74 & & 5.43 & 4.77 & 6.44 & & 4.97 \\
\hline $\mathrm{Eu}$ & 0.978 & 1.405 & & 1.012 & 0.979 & 1.113 & & 0.961 \\
\hline Gd & 4.69 & 5.84 & & 4.62 & 4.17 & 5.73 & & 4.65 \\
\hline $\mathrm{Tb}$ & 0.89 & 1.02 & & 0.88 & 0.74 & 0.99 & & 0.88 \\
\hline Dy & 5.04 & 6.13 & & 5.14 & 4.27 & 6.16 & & 5.19 \\
\hline Ho & 1.04 & 1.3 & & 1.00 & 0.88 & 1.31 & & 1.11 \\
\hline $\mathrm{Er}$ & 3.33 & 4.09 & & 3.06 & 2.66 & 4.15 & & 3.56 \\
\hline $\mathrm{Tm}$ & 0.553 & 0.587 & & 0.538 & 0.434 & 0.609 & & 0.543 \\
\hline $\mathrm{Tb}$ & 3.5 & 3.91 & & 3.53 & 2.79 & 4.02 & & 3.53 \\
\hline \multirow[t]{3}{*}{$\mathrm{Lu}$} & 0.559 & 0.583 & & 0.56 & 0.451 & 0.613 & & 0.540 \\
\hline & \multicolumn{6}{|l|}{ Tonalites } & \multicolumn{2}{|l|}{ Dikes } \\
\hline & LMT-10 & LMT-12 & LMT-17 & LMT-21 & LMT-27 & LMT-40 & LMT-25 & LMT26 \\
\hline $\mathrm{SiO}_{2}$ & 64.05 & 60.10 & 64.76 & 64.49 & 65.34 & 65.61 & 75.65 & 56.65 \\
\hline $\mathrm{Al}_{2} \mathrm{O}_{3}$ & 15.20 & 16.02 & 15.59 & 15.56 & 15.48 & 15.99 & 12.85 & 14.59 \\
\hline $\mathrm{Fe}_{2} \mathrm{O}_{3}^{*}$ & 6.52 & 8.30 & 6.23 & 5.38 & 5.81 & 5.56 & 1.96 & 7.25 \\
\hline $\mathrm{MnO}$ & 0.13 & 0.17 & 0.12 & 0.11 & 0.11 & 0.09 & 0.04 & 0.12 \\
\hline $\mathrm{MgO}$ & 1.77 & 2.50 & 1.60 & 1.61 & 1.33 & 1.48 & 0.30 & 7.05 \\
\hline $\mathrm{CaO}$ & 4.57 & 5.62 & 4.36 & 4.82 & 3.63 & 3.27 & 1.40 & 7.88 \\
\hline $\mathrm{Na}_{2} \mathrm{O}$ & 4.05 & 3.49 & 4.16 & 4.35 & 4.92 & 4.09 & 4.22 & 2.19 \\
\hline $\mathrm{K}_{2} \mathrm{O}$ & 1.86 & 1.78 & 1.96 & 1.90 & 1.67 & 2.22 & 3.10 & 1.83 \\
\hline $\mathrm{TiO}_{2}$ & 0.75 & 0.93 & 0.66 & 0.70 & 0.68 & 0.717 & 0.26 & 0.59 \\
\hline $\mathrm{P}_{2} \mathrm{O}_{5}$ & 0.29 & 0.23 & 0.26 & 0.23 & 0.51 & 0.30 & 0.06 & 0.16 \\
\hline LOI & 1.60 & 1.26 & 1.23 & 1.16 & 0.94 & 1.34 & 0.83 & 1.37 \\
\hline Total & 100.79 & 100.41 & 100.93 & 100.30 & 100.40 & 100.67 & 100.66 & 99.69 \\
\hline $\mathrm{Rb}$ & 47 & 100 & 64 & 47 & 39 & 68 & 61 & 53 \\
\hline $\mathrm{Sr}$ & 312 & 338 & 363 & 382 & 334 & 329 & 160 & 266 \\
\hline $\mathrm{Y}$ & 27 & 32 & 38 & 27 & 32 & 27 & 17 & 12 \\
\hline $\mathrm{Zr}$ & 110 & 117 & 127 & 131 & 144 & 171 & 185 & 106 \\
\hline
\end{tabular}




\begin{tabular}{|c|c|c|c|c|c|c|c|c|}
\hline & \multicolumn{6}{|l|}{ Tonalites } & \multicolumn{2}{|l|}{ Dikes } \\
\hline & LMT-10 & LMT-12 & LMT-17 & LMT-21 & LMT-27 & LMT-40 & LMT-25 & LMT26 \\
\hline $\mathrm{Nb}$ & 4 & 7 & 7 & 7 & 9 & 7 & 7 & 5 \\
\hline $\mathrm{Ba}$ & 474 & 346 & 558 & 600 & 573 & 732 & 1439 & 537 \\
\hline $\mathrm{Cs}$ & 1.5 & 3.7 & & & 3.5 & 4.5 & 0.6 & 1.8 \\
\hline $\mathrm{Hf}$ & 3.1 & 4.1 & & & 4.8 & 4.6 & 6.4 & 3.6 \\
\hline $\mathrm{Ta}$ & 1.11 & 1.29 & & & 1.69 & 1.4 & 3.14 & 0.98 \\
\hline $\mathrm{Tl}$ & 0.12 & 0.65 & & & 0.19 & 0.52 & 0.32 & 0.36 \\
\hline Th & 2.8 & 3.2 & & & 2.9 & 3.1 & 4.5 & 11.0 \\
\hline $\mathrm{U}$ & 1.0 & 1.0 & & & 1.0 & 1.2 & 1.6 & 3.8 \\
\hline $\mathrm{La}$ & 13.5 & 21.4 & & & 21.1 & 19.3 & 56.7 & 24.1 \\
\hline $\mathrm{Ce}$ & 33.9 & 48.1 & & & 48.7 & 42.4 & 99.5 & 51.1 \\
\hline $\operatorname{Pr}$ & 4.072 & 6.006 & & & 6.190 & 5.11 & 9.798 & 5.544 \\
\hline $\mathrm{Nd}$ & 18.3 & 28.8 & & & 30.6 & 21.8 & 38.1 & 23.9 \\
\hline $\mathrm{Sm}$ & 4.4 & 6.74 & & & 7.29 & 4.83 & 5.49 & 4.4 \\
\hline $\mathrm{Eu}$ & 1.136 & 1.534 & & & 1.923 & 1.39 & 1.515 & 1.053 \\
\hline $\mathrm{Gd}$ & 3.89 & 6.03 & & & 6.39 & 4.57 & 3.73 & 3.12 \\
\hline $\mathrm{Tb}$ & 0.72 & 1.06 & & & 1.11 & 0.81 & 0.54 & 0.46 \\
\hline Dy & 4.07 & 6.44 & & & 6.54 & 4.66 & 3.01 & 2.55 \\
\hline Ho & 0.84 & 1.35 & & & 1.37 & 0.98 & 0.66 & 0.51 \\
\hline $\mathrm{Er}$ & 2.5 & 4.18 & & & 4.2 & 2.95 & 2.36 & 1.6 \\
\hline $\mathrm{Tm}$ & 0.389 & 0.581 & & & 0.567 & 0.433 & 0.335 & 0.197 \\
\hline $\mathrm{Tb}$ & 2.45 & 3.84 & & & 3.72 & 2.95 & 2.49 & 1.31 \\
\hline $\mathrm{Lu}$ & 0.402 & 0.568 & & & 0.554 & 0.432 & 0.424 & 0.198 \\
\hline
\end{tabular}

textures have not been modified by metamorphic overprints (Fig. 3e and f). According to preliminary electron probe microanalysis data of amphibole and feldspars, the emplacement level of the pluton should have been shallow, at least in the late stages. This shallow emplacement level is also evidenced by graphic textures (Fig. 3e) detected in some trondhjemites.

\subsection{Geochemistry}

Major, trace-, and RE elements were analyzed for 8 whole-rock samples of the leucocratic facies, 6 samples of the melanocratic facies, 1 basic dike, and 1 acidic dike (Table 1). The analyses were performed at the Activation Laboratories (Canada), by Fusion-ICP for major oxides and by Fusion-ICP MS for trace and RE elements.

The major element composition characterizes the rocks as tonalites-trondhjemites (Fig. 4a), of low-Al and medium-K contents. The classification of trondhjemites is in accordance with the definition of Barker (1979), with $\mathrm{SiO}_{2}$ in the range $70.7-75.5 \%, \quad \mathrm{FeO}^{*}+\mathrm{MgO}=2.3-3.9 \%$, $\mathrm{CaO}=1.4-2.4 \%, \mathrm{Na}_{2} \mathrm{O}=4.0-4.5 \%$, and relatively high values $\mathrm{K}_{2} \mathrm{O},=2.4-3.0 \%$. The $\mathrm{SiO}_{2}$ range of the tonalites is low, $60.1-65.6 \%$. However, the general chemical features are quite similar to those of the trondhjemites, hence they are considered as cogenetic. The sodic character dominates over potassic $\left(\mathrm{Na}_{2} \mathrm{O} / \mathrm{K}_{2} \mathrm{O}=1.8-3\right.$ for the tonalites and 1.32.0 for the trondhjemites), and all the rocks are metaluminous (Fig. 4b). The two samples of dikes $\left(\mathrm{SiO}_{2}=56.7\right.$ and $75.7 \%$ ) do not show behaviour similar to that of the pluton.

Despite the compositional gap recognized between the tonalitic and trondhjemitic rocks, the Harker diagrams (Fig. 5) show good negative trends for $\mathrm{MgO}, \mathrm{FeO}, \mathrm{CaO}$, $\mathrm{TiO}_{2}$, and $\mathrm{Al}_{2} \mathrm{O}_{3}$. For $\mathrm{Na}_{2} \mathrm{O}$, no trend can be delineated, while $\mathrm{K}_{2} \mathrm{O}$ increases for the trondhjemites. This different behaviour for the alkalies is observed in the more sodic character of the tonalites compared to the trondhjemites (Fig. 4b). In the AFM diagram (Irvine and Baragar, 1971) both the tonalites and trondhjemites show a calc-alkaline signature.

$\mathrm{Rb}(<100 \mathrm{ppm})$ and $\mathrm{Sr}(<382 \mathrm{ppm})$ are low, $\mathrm{Y}$ (generally $27-38 \mathrm{ppm})$ and $\mathrm{Ba}(346-600 \mathrm{ppm}$ for tonalites and 817 $941 \mathrm{ppm}$ for trondhjemites) are moderate. The low $\mathrm{Sr} / \mathrm{Y}$ and moderate contents of Y (Fig. 6) are characteristic of low-Al TTD (tonalites, trondhjemites and dacites), which also characterize the calc-alkaline andesite-dacite-rhyolite suites from continental and island arcs. Concentrations of $\mathrm{Zr}$ are low to moderate, $110-171 \mathrm{ppm}$ for tonalites and $165-$ $212 \mathrm{ppm}$ for trondhjemites.

Tonalites and trondhjemites have very coherent REE patterns and show little variation in both overall abundance and profile shape (Fig. 7). Total REE analyzed are low (121-154 ppm for trondhjemites, 91-140 ppm for tonalites), and very little increase of total REE accompanies the increase in $\mathrm{SiO}_{2}$. The patterns show slight LREE enrichment and flat HREE behaviour $\left(\mathrm{La} / \mathrm{Sm}_{\mathrm{N}}=1.8-3.2\right.$ and $\mathrm{La} /$ $\left.\mathrm{Yb}_{\mathrm{N}}=3.7-5.5\right)$. The Eu negative anomaly is slight to moderate $\left(\mathrm{Eu} / \mathrm{Eu}^{*}=0.74-0.90\right.$ for tonalites and $0.56-0.68$ for trondhjemites) and, together with the clear decrease of $\mathrm{Sr}$ with increasing $\mathrm{SiO}_{2}$ content, suggests progressive removal of plagioclase from the magma. The low $(\mathrm{La} / \mathrm{Yb})_{\mathrm{N}}$ and relatively high $(\mathrm{Yb})_{\mathrm{N}}$ values are also characteristics of the 

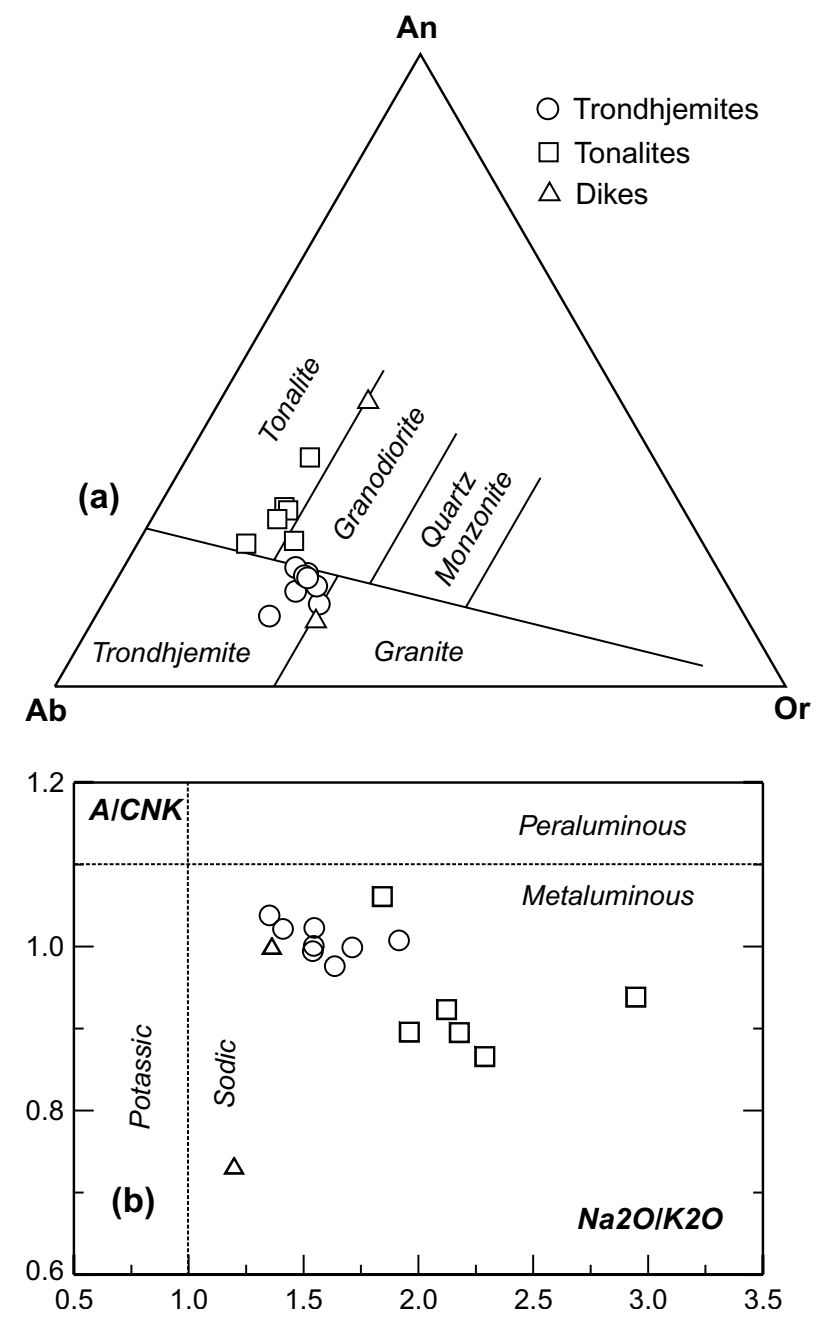

Fig. 4. (a) Classification of trondhjemites and tonalites, after O'Connor (1965), based on normative Ab, An, and Or. (b) Relation between A/ CNK (molar) and $\mathrm{Na}_{2} \mathrm{O} / \mathrm{K}_{2} \mathrm{O}$, showing the sodic and metaluminous character of these rocks. The tonalites are more sodic and metaluminous than the trondhjemites.

low-Al (or high-Yb) TTD (Martin, 1986; Drummond and Defant, 1990). In contrast, the basic and acidic dikes show quite different patterns, indicating a different magmatic origin.

Both the tonalites and trondhjemites have all the major, trace, and REE chemical characteristics of low-Al TTD. The partial melting models of Drummond and Defant (1990) and Drummond et al. (1996) depicted for these rocks indicate derivation from a plagioclase-bearing basaltic source or, alternatively, plagioclase fractionation from mantle-derived magmas. The slight enrichment in the LIL elements like $\mathrm{Sr}, \mathrm{Rb}, \mathrm{K}$, Th, and $\mathrm{U}$ observed at Las Matras is indicative of a slight crustal signature component; this can be achieved through either melting of basaltic material derived from a depleted mantle or direct derivation from an enriched mantle. The fact that no other mafic magma is found associated with the pluton complicates these interpretations. In any case, the $\mathrm{Rb}$ vs. $\mathrm{Y}+\mathrm{Nb}$ discrimination
(Pearce et al., 1984) as well as the $\mathrm{La} / \mathrm{Yb}$ values $(>2.3)$ agree with an environment of continental magmatic arc.

In contrast, the high-Al subtype TTD has quite different trace and REE patterns because of the involvement of garnet in petrogenesis. These rocks, which are quite abundant in the Archean gneissic terranes, are explained as a much higher pressure melting product of hot slab basalts transformed to amphibolite and eclogite at a deeper and more oceanward position than the calc-alkaline arc (Martin, 1986, 1987; Drummond and Defant, 1990). They have also been related to mantle delamination processes (Kay and Mahlburg Kay, 1993).

\subsection{Age}

To constrain the age of the Las Matras pluton, one $\mathrm{Rb}-\mathrm{Sr}$ errorchron, one $\mathrm{Sm}-\mathrm{Nd}$ isochron, and a new $\mathrm{K}-\mathrm{Ar}$ date have been obtained in addition to the $\mathrm{K}-\mathrm{Ar}$ dates reported by Linares et al. (1980). A U-Pb zircon dating is presently in process.

The $\mathrm{Rb}-\mathrm{Sr}$ method was applied using 14 whole-rock samples from the tonalitic as well as the trondhjemitic facies, including the 2 dikes. For the $\mathrm{Sm}-\mathrm{Nd}$ method, 1 trondhjemitic and 2 tonalitic whole-rock samples, together with 2 amphibole separates from the tonalites were used. $\mathrm{Rb}$ and $\mathrm{Sr} \mathrm{XRF}$ analyses, the isotope dilution technique for $\mathrm{Sm}-\mathrm{Nd}$ analyses (using a combined ${ }^{149} \mathrm{Sm}-{ }^{150} \mathrm{Nd}$ spike according to the technique described by Sato et al., 1995), as well as the mass spectrometry for $\mathrm{Sm}, \mathrm{Nd}$, and $\mathrm{Sr}$, were carried out at the Centro de Pesquisas Geocronologicas, São Paulo. The isotopic ratios were measured using the VG 354 mass spectrometer with multiple and single collector systems. Only the extraction of natural $\mathrm{Sr}$ through cation exchange columns was performed at the Centro de Investigaciones Geológicas, La Plata. K-Ar amphibole dating from the tonalite was also carried out at the Centro de Pesquisas Geocronológicas.

$\mathrm{Rb}-\mathrm{Sr}$ whole-rock dating (Fig. 8a, Table 2) show an acceptable alignment of 10 samples within a low range of ${ }^{87} \mathrm{Rb} /{ }^{86} \mathrm{Sr}(<1.2)$. The age obtained was $1212 \pm 47 \mathrm{Ma}$ $(2 \sigma)$, initial ${ }^{87} \mathrm{Sr} /{ }^{86} \mathrm{Sr} 0.7030 \pm 0.0004$, and MSWD 3.7. It was not possible to separate the tonalitic facies from the trondhjemitic within the errorchron. The two samples of dikes did not align with the pluton. Two other trondhjemitic samples (LMT-8 and LMT-14) were also excluded because of their scattered positions. Taking into account that the pluton does not show any textural evidence of ductile deformation and metamorphism, this date is considered to be related to the crystallization age. The low initial $\mathrm{Sr}$ ratio is indicative of an only slightly evolved common source for both the tonalitic and trondhjemitic rocks.

The five samples analyzed by the $\mathrm{Sm}-\mathrm{Nd}$ method define an acceptable isochron (Fig. 8b, Table 2) of $1188 \pm 47 \mathrm{Ma}$, and MSWD 0.3. The model ages $\left(T_{\mathrm{DM}}\right)$ calculated according to DePaolo (1981) for the whole-rock samples are in the range $1551-1604 \mathrm{Ma}$. The $\epsilon \mathrm{Nd}_{(1200)}$ for these samples is 


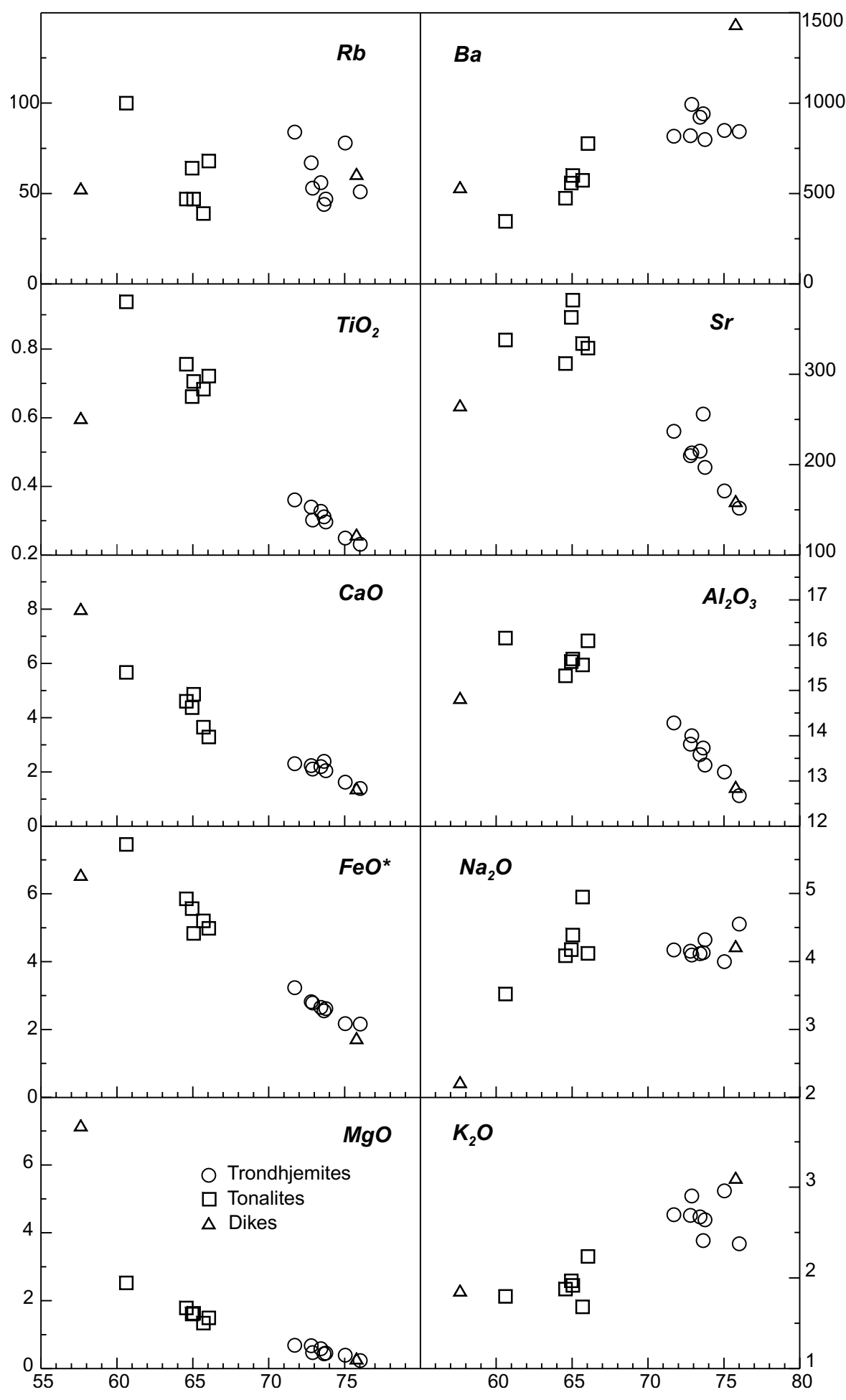

Fig. 5. Harker diagrams (dry bases) for the rocks of the Las Matras pluton, for major elements, $\mathrm{Rb}, \mathrm{Sr}$ and $\mathrm{Ba} \mathrm{SiO}_{2}$ ranges are $60.1-65.6 \%$ for tonalites, and $70.7-75.5 \%$ for trondhjemites (see Table 1). A compositional gap can be seen between the tonalites and trondhjemites.

very close, between +1.6 and +1.8 , indicating a "depleted" source, less evolved than CHUR for the time of crystallization. The low values of $\epsilon \operatorname{Sr}_{(1200)}(-4.5$ to +4.8$)$ are also indications of their depleted character. The rough coincidence within error ranges of the $\mathrm{Sm}-\mathrm{Nd}$ and the $\mathrm{Rb}-\mathrm{Sr}$ dates indicates that an average of $1200 \mathrm{Ma}$ can be reason- ably proposed as the crystallization age for the Las Matras pluton.

If we consider a linear strontium isotopic evolution of BABI through time (Fig. 9a), with ${ }^{87} \mathrm{Sr} /{ }^{86} \mathrm{Sr}$ from 0.699 to $0.704(\mathrm{Rb} / \mathrm{Sr}$ 0.027; Faure, 1986) during the $4.5 \mathrm{Ga}$, the ${ }^{87} \mathrm{Sr} /{ }^{86} \mathrm{Sr}$ value for $1.2 \mathrm{Ga}$ (crystallization age of the Las 


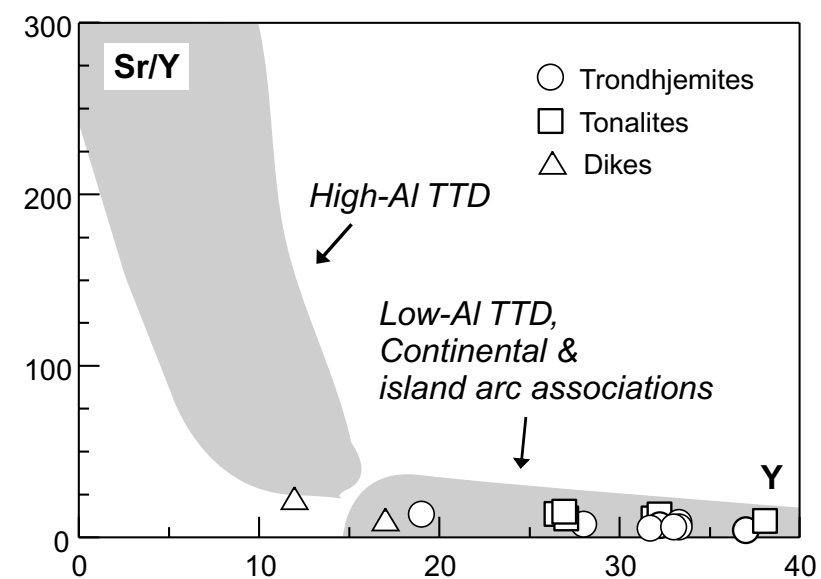

Fig. 6. Sr/Y vs Y diagram (Drummond and Defant, 1990). The rocks of the Las Matras pluton plot in the low-Al TTD field, which also characterizes the calc-alkaline andesite-dacite-rhyolite suites from continental and island arcs.

Matras pluton) is 0.7028 , which is very close to the value of $0.7030 \pm 0.0003$ obtained from the $\mathrm{Rb}-\mathrm{Sr}$ errorchron. This could explain a direct mantle derivation for the magma at this time. However, if we consider the linear evolution of a depleted mantle ( $\mathrm{Rb} / \mathrm{Sr} 0.016$; Faure, 1986), the ${ }^{87} \mathrm{Sr} /{ }^{86} \mathrm{Sr}$ of 0.7030 obtained for the Las Matras pluton can also be explained as a result of fusion of crustal material extracted from that depleted mantle at $1.6 \mathrm{Ga}$ (Fig. 9a). A crustal residence time of $\sim 400$ million years (up to $1.2 \mathrm{Ga}$ ) can be calculated in a closed system having a $\mathrm{Rb} / \mathrm{Sr}$ ratio of approximately 0.12 . After this, partial fusion and complete homogenization of the $\mathrm{Rb}-\mathrm{Sr}$ system could have occurred, yielding a $1.2 \mathrm{Ga}$ pluton with ${ }^{87} \mathrm{Sr} /{ }^{86} \mathrm{Sr}=0.7030$. The low values of $\mathrm{Rb} / \mathrm{Sr}(0.11-0.39)$ found in the rocks can support this evolution from a depleted mantle model rather than from a normal mantle one.

The above Sr depleted-mantle model age of $1.6 \mathrm{Ga}$ agrees well with the Nd $T_{\mathrm{DM}}$ model ages (1551-1604 Ma) calculated after DePaolo (1981; Fig. 9b). This coincidence favors this refusion hypothesis of material derived from a depleted mantle. Nevertheless, the possibility of derivation from a depleted mantle contaminated by recycled sediments (or an enriched mantle) in a subduction zone cannot be discarded, as can be seen by the poorly defined epsilon values $(\epsilon \mathrm{Nd}+1.8$ to +1.7 , and $\epsilon \mathrm{Sr}-4.5$ to +4.8$)$.

The $\mathrm{K}-\mathrm{Ar}$ date, obtained for amphibole separated from a tonalite, was $869 \pm 17 \mathrm{Ma}$ (Table 2). This value is closer to the published data in the range of 690-810 Ma (Linares et al., 1980). These dates, together with the 392-382 Ma KAr whole-rock dates (Linares et al., 1980) can suggest different degrees of resetting during the Early Paleozoic Famatinian orogeny that affected the central western Argentine region. Alternatively, they can represent two different thermal events, one in the Neoproterozoic and another during Early Paleozoic times (Linares et al., 1980; Sato et al., 1996; Tickyj, 1999). Up to now, we have not had evidence to support any of these alternative interpretations.
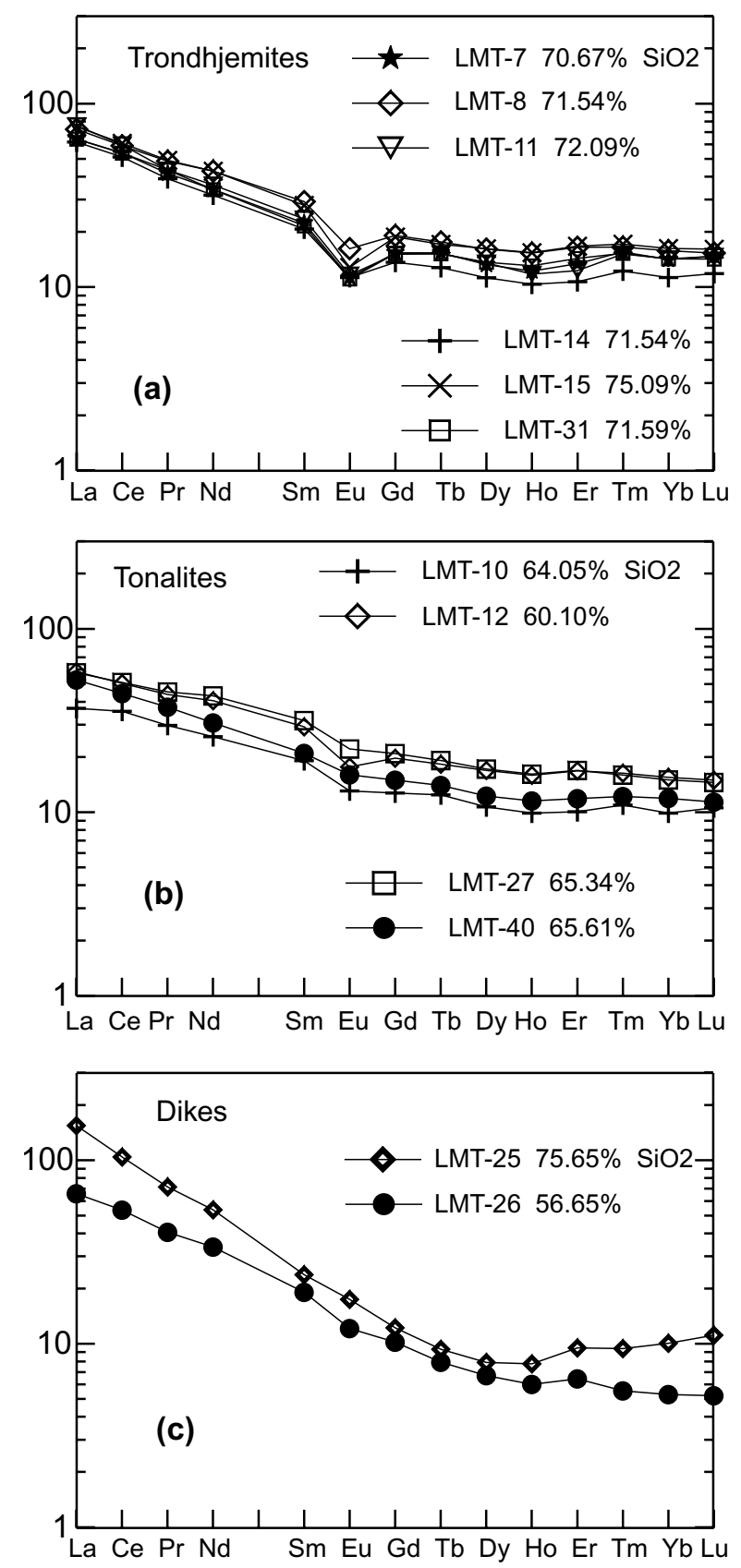

Fig. 7. Chondrite-normalized REE patterns for the (a) trondhjemites; (b) tonalites; and (c) dikes. The trondhjemites and tonalites show consistent patterns, with low $(\mathrm{La} / \mathrm{Yb})_{\mathrm{N}}$ and small negative Eu anomalies, typical of low-Al TTD. The two dikes show quite different patterns.

\subsection{Comparable Grenvillian basement rocks in Argentina}

To the north of Las Matras, Grenvillian-age basement rocks involved in the Early Paleozoic Famatinian orogeny of the southwestern margin of Gondwana are exposed at the following morphostructural units (cf. Fig. 10, Table 3).

Western Sierras Pampeanas. The northernmost exposure in the Western Sierras Pampeanas corresponds to the area of Sierra de Umango (Varela et al., 1996) where biotite schists, amphibolites, acidic gneisses, mafic gneisses, and marbles 

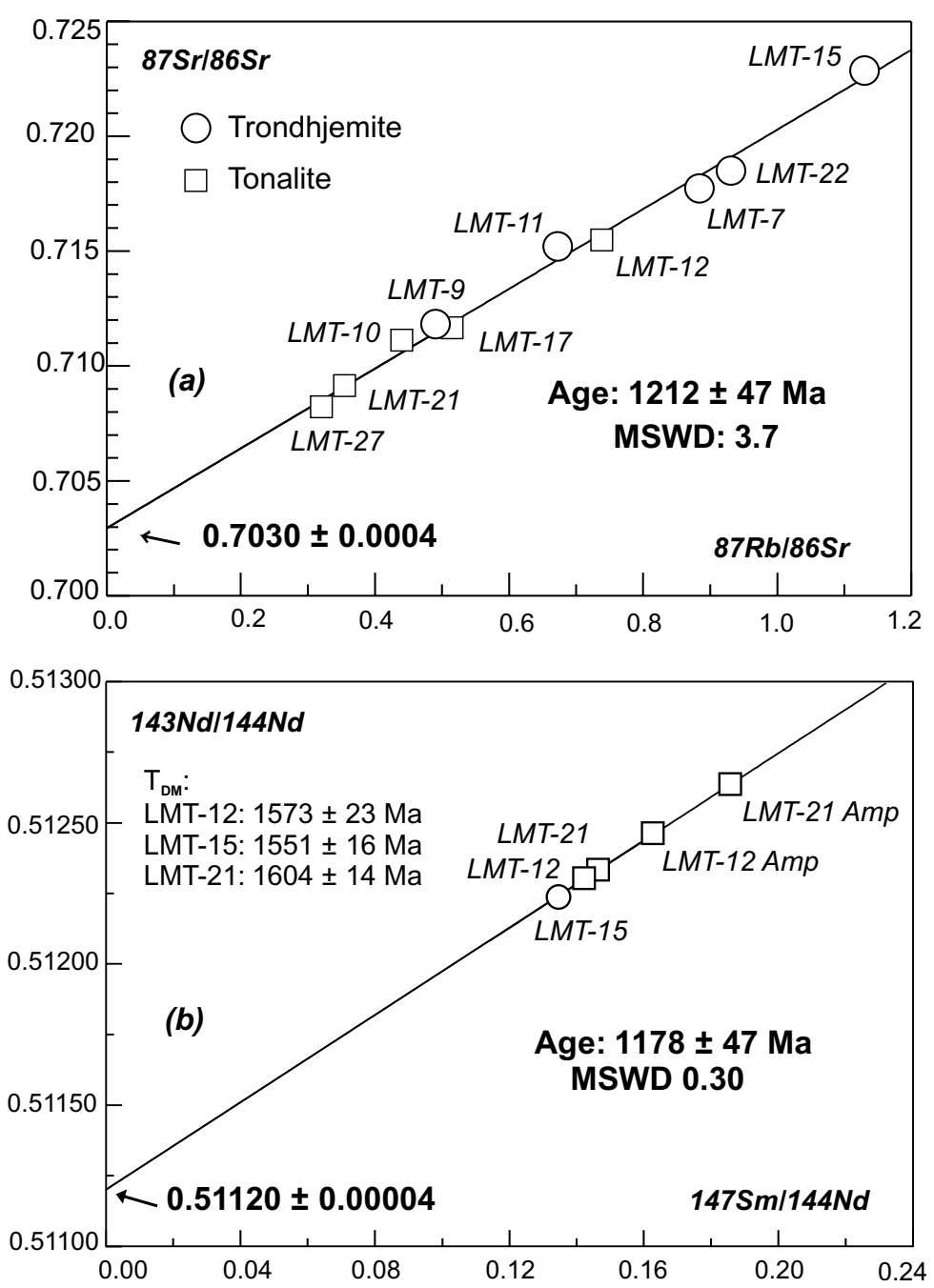

Fig. 8. (a) Rb-Sr whole rock errorchron; and (b) Sm-Nd whole rock-amphibole isochron for the Las Matras pluton. Both the trondhjemitic and tonalitic facies are aligned on the same isochrons, indicating that they are comagmatic.

occur. Metamorphic grades range from greenschist to granulite facies. The acidic gneisses yielded a whole rock $\mathrm{Rb}-\mathrm{Sr}$ isochron age of $1030 \pm 30 \mathrm{Ma}$, probably corresponding to the metamorphic process. The geochemistry of amphibolites has been interpreted as compatible with a magmatic arc or back arc environment (Vujovich and Kay, 1996).

To the southeast, at Sierra de Valle Fértil, an association of paragneisses, orthogneisses, and amphibolites of granulite facies have been described (Mirré, 1971); Cingolani (unpublished data) obtained a $\mathrm{Rb}-\mathrm{Sr}$ preliminary isochron of $963 \pm 86 \mathrm{Ma}$ (see Varela et al., 1996). The intermediate to basic rocks that intruded this basement in the southern continuation of the mountain chain (Sierra de la Huerta) have been interpreted as representing the root of a magmatic arc (Vujovich et al., 1996; Castro de Machuca et al., 1996a), probably of island type (Castro de Machuca et al., 1996b).

In the Sierra de Pie de Palo, greenschist to granulite facies rocks (see synthesis in Vujovich and Kay, 1998) comprise ortho- and paragneisses and schists, migmatites, as well as mafic-ultramafic associations (peridotites, serpentinites, metagabbros, metadiorites, amphibolites, mafic schists) and marbles. These rocks yielded a crystallization $\mathrm{U}-\mathrm{Pb}$ age of $1105 \pm 79 \mathrm{Ma}$ and $\mathrm{a}{ }^{207} \mathrm{~Pb} /{ }^{206} \mathrm{~Pb}$ metamorphism date of 1060-1080 Ma (McDonough et al., 1993; recalculated values in Ramos et al., 1998). Rb-Sr metamorphism ages have been reported by Varela and Dalla Salda (1992) - $1027 \pm 57 \mathrm{Ma}$, reference isochron, and Pankhurst and Rapela (1998) - $1021 \pm 12 \mathrm{Ma}$. The geochemical study of these rocks allowed Vujovich and Kay $(1996,1998)$ to postulate a tectonic setting within an oceanic arc/back arc environment.

At the western rim of Sierra de Pie de Palo, there are carbonate and clastic shelf sediments affected by lowgrade metamorphism (Vujovich and Ramos, 1994; Dalla Salda and Varela, 1984; Ramos et al., 1998). These rocks show some lithological similarities with the Cambro-Ordovician carbonate shelf deposits associated with the belt with 
Table 2

Analytical results of $\mathrm{Rb}-\mathrm{Sr}, \mathrm{Sm}-\mathrm{Nd}$, and $\mathrm{K}-\mathrm{Ar}$ datings from the Las Matras pluton and dikes

(Values obtained for standards: NBS-987, ${ }^{87} \mathrm{Sr} /{ }^{86} \mathrm{Sr} 0.71026$; La Jolla, ${ }^{143} \mathrm{Nd} /{ }^{144} \mathrm{Nd} 0.511847 . T_{\mathrm{DM}}$ model ages calculated according to the single-stage method of DePaolo $(1981)$ )

\begin{tabular}{|c|c|c|c|c|c|c|c|c|c|}
\hline Sample & Material & $\mathrm{Rb}(\mathrm{ppm})$ & $\mathrm{Sr}(\mathrm{ppm})$ & ${ }^{87} \mathrm{Rb} /{ }^{86} \mathrm{Sr}$ & ${ }^{87} \mathrm{Sr} /{ }^{86} \mathrm{Sr}$ & & & & \\
\hline \multicolumn{10}{|c|}{$R b-S r$ analytical results } \\
\hline LMT-7 & Trondhjemite & 68.1 & 223.2 & $0.88387 \pm 0.001767$ & $0.71772 \pm 0.00009$ & & & & \\
\hline LMT-8 & Trondhjemite & 76.5 & 231.2 & $0.95875 \pm 0.01918$ & $0.71733 \pm 0.00009$ & & & & \\
\hline LMT-9 & Trondhjemite & 43.9 & 259.6 & $0.48989 \pm 0.00979$ & $0.71182 \pm 0.00008$ & & & & \\
\hline LMT-10 & Tonalite & 55.4 & 365.5 & $0.43913 \pm 0.00878$ & $0.71109 \pm 0.00012$ & & & & \\
\hline LMT-11 & Trondhjemite & 48.7 & 209.7 & $0.67236 \pm 0.01345$ & $0.71519 \pm 0.00007$ & & & & \\
\hline LMT-12 & Tonalite & 87.8 & 345.2 & $0.73715 \pm 0.01474$ & $0.71545 \pm 0.00007$ & & & & \\
\hline LMT-14 & Trondhjemite & 56.2 & 232.2 & $0.66418 \pm 0.01328$ & $0.71591 \pm 0.00008$ & & & & \\
\hline LMT-15 & Trondhjemite & 65.8 & 168.8 & $1.12967 \pm 0.02259$ & $0.72285 \pm 0.00012$ & & & & \\
\hline LMT-17 & Tonalite & 64.1 & 361.2 & $0.51383 \pm 0.01027$ & $0.71165 \pm 0.00008$ & & & & \\
\hline LMT-21 & Tonalite & 47.3 & 387.0 & $0.35375 \pm 0.00707$ & $0.70912 \pm 0.00011$ & & & & \\
\hline LMT-22 & Trondhjemite & 47.3 & 151.2 & $0.93064 \pm 0.01861$ & $0.71849 \pm 0.00010$ & & & & \\
\hline LMT-25 & Dike & 54.8 & 159.8 & $0.99269 \pm 0.01985$ & $0.71634 \pm 0.00009$ & & & & \\
\hline LMT-26 & Dike & 49.5 & 266.8 & $0.53716 \pm 0.01074$ & $0.71346 \pm 0.00008$ & & & & \\
\hline LMT-27 & Tonalite & 37.2 & 336.8 & $0.31957 \pm 0.00639$ & $0.70819 \pm 0.00009$ & & & & \\
\hline \multicolumn{10}{|c|}{ Sm-Nd analytical results } \\
\hline Sample & Material & $\mathrm{Sm}(\mathrm{ppm})$ & $\mathrm{Nd}(\mathrm{ppm})$ & ${ }^{147} \mathrm{Sm} /{ }^{144} \mathrm{Nd}$ & ${ }^{143} \mathrm{Nd} /{ }^{144} \mathrm{Nd}$ & $T_{\mathrm{DM}}(\mathrm{Ma})$ & $\epsilon \mathrm{Nd}_{(0)}$ & $\epsilon \mathrm{Nd}_{(1200)}$ & $\epsilon \mathrm{Sr}_{(1200)}$ \\
\hline LMT-12 & Tonalite & 5.4 & 23.0 & $0.1422 \pm 0.0005$ & $0.512303 \pm 0.000011$ & 1572 & -6.53 & +1.81 & -4.51 \\
\hline LMT-12Amp & Amphibole & 10.3 & 38.5 & $0.1626 \pm 0.0005$ & $0.512462 \pm 0.000006$ & & & & \\
\hline LMT-15 & Trondhjemite & 5.4 & 24.1 & $0.1347 \pm 0.0005$ & $0.512237 \pm 0.000008$ & 1551 & -7.82 & +1.67 & +4.80 \\
\hline LMT-21 & Tonalite & 4.9 & 20.4 & $0.1464 \pm 0.0005$ & $0.512332 \pm 0.000005$ & 1605 & -5.97 & +1.73 & -0.80 \\
\hline LMT-21Amp & Amphibole & 22.6 & 73.5 & $0.1857 \pm 0.0006$ & $0.512634 \pm 0.000004$ & & & & \\
\hline \multicolumn{10}{|c|}{$K-$ Ar analytical results } \\
\hline Sample & Material & $\% \mathrm{~K}$ & ${ }^{40} \mathrm{Ar} \operatorname{Rad} 10^{6}(\mathrm{ccSTP} / \mathrm{g})$ & $\%{ }^{40} \mathrm{Ar} \mathrm{atm}$ & Age (Ma) & & & & \\
\hline LMT-21Amp & Amphibole & $0.6774 \pm 0.0049$ & 29.39 & 8.61 & $869.3 \pm 17.0$ & & & & \\
\hline
\end{tabular}


Table 3

Summary of ages, lithologies, metamorphic grades, and tectonic environments for exposures comprising the belt with Grenvillian-age rocks in central western Argentina. At Las Matras, a non-deformed ca. 1200 Ma magmatic arc is registered. To the north the ages represent igneous crystallization $(1118 \pm 54-1069 \pm 36 \mathrm{Ma})$ and metamorphism (less than 1083-1021 $\pm 12 \mathrm{Ma})$. These data are suggestive of a non-homogeneous tectonic evolution for the entire Argentine belt, although the depleted $\mathrm{Sr}$ and $\mathrm{Nd}$ isotopic signatures are similar

(Numbers in square brackets refer to: [1] Varela et al., 1996; [2] Vujovich and Kay, 1996; [3] Mirré, 1971; [4] Vujovich et al., 1996; [5] Castro de Muchuca et al., 1996a,b; [6] Pontoriero and Castro de Machuca, 1999; [7] McDonough et al., 1993; [8] Ramos et al., 1998; [9] Varela and Dalla Salda, 1992; [10] Pankhurst and Rapela, 1998; [11] Ramos et al., 1996; [12] Vujovich and Kay, 1998; [13] Abruzzi et al., 1993; [14] Mahlburg Kay et al., 1996; [15] Ramos and Basei, 1997; [16] Basei et al., 1998; [17] Caminos, 1993; [18] Vujovich, 1998; [19] Astini et al., 1996; [20] Cingolani and Varela, 1999; [21] Núñez, 1979; [22] this study; [23] Linares et al., 1980)

\begin{tabular}{|c|c|c|c|c|}
\hline Locality & $\begin{array}{l}\text { Date - method }{ }^{\mathrm{a}} \text { - material } \\
{[\text { References }]}\end{array}$ & Dated rock type & Dated process & $\begin{array}{l}\text { General lithology, } \\
\text { metamorphism, tectonics } \\
\text { [References] }\end{array}$ \\
\hline
\end{tabular}

Western sierras pampeanas

Sierra de Umango $\quad 1030 \pm 30 \mathrm{Ma}-\mathrm{Rb} / \mathrm{Sr}-\mathrm{wr}$ isochron $\left(\mathrm{Sr}_{\mathrm{i}} 0.7026 \pm 0.0003\right)$ [1]

Sierra de Valle Fértil-Sierra de la $963 \pm 86 \mathrm{Ma}-\mathrm{Rb} / \mathrm{Sr}-\mathrm{wr}$ isochron [in 1]

Acidic orthogneiss

Metamorphism?

Huerta

Sierra de Pie de Palo

$1060-1080 \mathrm{Ma}{ }^{207} \mathrm{~Pb} /{ }^{206} \mathrm{~Pb}-$ zircon

Orthogneiss

Metamorphism

$1105 \pm 79 \mathrm{Ma}-\mathrm{U} / \mathrm{Pb}-$

zircon $[7,8]$

$1027 \pm 59 \mathrm{Ma}-\mathrm{Rb} / \mathrm{Sr}-\mathrm{wr}$

reference isochron $\left(\mathrm{Sr}_{\mathrm{i}}\right.$

$0.7043 \pm 0.0002$ ) [9]

$1021 \pm 12 \mathrm{Ma}-\mathrm{Rb} / \mathrm{Sr}-\mathrm{wr}$

isochron $\left(\mathrm{Sr}_{\mathrm{i}} 0.7045 \pm 0.0003\right)$

[10]

$606.1 \pm 0.7 \mathrm{Ma}-\mathrm{Ar} / \mathrm{Ar}-$

amph

$777.8 \pm 3.1 \mathrm{Ma}-\mathrm{Ar} / \mathrm{Ar}-$

amph $[8,11]$

Precordillera

$1102 \pm 6 \mathrm{Ma}-\mathrm{U} / \mathrm{Pb}-$ zircon

Mafic amphibolite

$$
\begin{aligned}
& 1118 \pm 54 \mathrm{Ma}-\mathrm{U} / \mathrm{Pb}- \\
& \text { zircon } \\
& \text { ca. } 1083 \mathrm{Ma}{ }^{207} \mathrm{~Pb} /{ }^{206} \mathrm{~Pb}- \\
& \text { zircon } \\
& T_{\mathrm{DM}} 1560-1685 \mathrm{Ma}-\mathrm{Sm} / \mathrm{Nd} \\
& -\mathrm{wr}\left(\epsilon \mathrm{Nd}_{1100}+2.0 \text { to }+2.7\right) \\
& T_{\mathrm{DM}} 1340-1470 \mathrm{Ma}-\mathrm{Sm} / \mathrm{Nd} \\
& -\mathrm{wr}\left(\epsilon \mathrm{Nd}_{1100}+2.1 \text { to }+3.5\right) \\
& T_{\mathrm{DM}} 800-1000 \mathrm{Ma}-\mathrm{Sm} / \mathrm{Nd} \\
& -\mathrm{wr}\left(\epsilon \mathrm{Nd}_{1100}>+7.0\right) \\
& { }^{206} \mathrm{~Pb} /{ }^{204} \mathrm{~Pb} 17.1-17.8 \\
& { }^{207} \mathrm{~Pb} /{ }^{204} \mathrm{~Pb} 15.42-15.49 \\
& { }^{208} \mathrm{~Pb} /{ }^{204} \mathrm{~Pb} 36.6-37.4 \\
& {[13,14]}
\end{aligned}
$$

Schists, gneisses, migmatites

Orthogneiss

Ign. crystallization

Metamorphism

Metamorphism
Acidic gneiss

Mafic amphibolite

Mafic granulite

Mafic amphibolite

Acidic orthogneiss
Ign. crystallization

Ign. crystallization

Metamorphism

Biotite-schists, acidic gneisses, amphibolites, mafic gneiss, marbles. Green-schist to granulite facies. Magmatic arc or back arc environment. [1,2]

Orthogneiss, paragneiss, amphibolites. Intruded by tonalites, quartz diorites, mafic to ultramafic rocks. Amphibolite to granulite facies. Root of magmatic arc. [3-6] Peridotites, meta-gabbros, serpentinites, amphibolites, flsbio-grn-plg-schists and gneisses, marbles. Oceanic arcback arc complex. $[4,12]$

Plagioclase-bearing amphibolite, biotite-bearing acidic gneiss, pyroxene-garnet granulite gneisses. Protoliths formed in an oceanic arc-back arc environment near a continental margin. [13,14] 
Table 3 (continued)

\begin{tabular}{|c|c|c|c|c|}
\hline Locality & $\begin{array}{l}\text { Date - method }{ }^{\mathrm{a}} \text { - material } \\
\text { [References }]\end{array}$ & Dated rock type & Dated process & $\begin{array}{l}\text { General lithology, } \\
\text { metamorphism, tectonics } \\
\text { [References] }\end{array}$ \\
\hline \multicolumn{5}{|l|}{ Frontal Cordillera } \\
\hline \multirow[t]{2}{*}{ Cordón del Portillo } & $\begin{array}{l}1069 \pm 36 \mathrm{Ma}-\mathrm{U} / \mathrm{Pb}- \\
\text { zircon [15] }\end{array}$ & Quartz-plg-gneiss & Ign. crystallization & $\begin{array}{l}\text { Greenschist facies gneisses and } \\
\text { schists, amphibolites, marbles. } \\
{[16-18]}\end{array}$ \\
\hline & $\begin{array}{l}T_{\mathrm{DM}} 1427-1734 \mathrm{Ma}-\mathrm{Sm} / \mathrm{Nd} \\
-\mathrm{wr}[16]\end{array}$ & Schists and gneisses & & \\
\hline \multicolumn{5}{|l|}{ San Rafael Block } \\
\hline \multirow[t]{2}{*}{ Ponon Trehue area } & $\begin{array}{l}\text { Preliminary Grenvillian } \mathrm{U}-\mathrm{Pb} \\
\text { age [in 19] }\end{array}$ & Granodiorites to tonalites & Metamorphism? & $\begin{array}{l}\text { Mylonitized acidic } \\
\text { orthogneisses, micaschists and } \\
\text { migmatites. Acidic to } \\
\text { intermediate granitoids (with } \\
\text { ductile deformation), and } \\
\text { pegmatitic and aplitic veins. [21] }\end{array}$ \\
\hline & $\begin{array}{l}1063 \pm 106 \mathrm{Ma}-\mathrm{Rb} / \mathrm{Sr}-\mathrm{wr} \\
\text { isochron }\left(\mathrm{Sr}_{\mathrm{i}} 0.7032 \pm 0.0004\right) \\
{[20]}\end{array}$ & & & \\
\hline \multicolumn{5}{|l|}{ Las Matras Block } \\
\hline \multirow[t]{4}{*}{ Las Matras area } & $\begin{array}{l}1212 \pm 47 \mathrm{Ma}-\mathrm{Rb} / \mathrm{Sr}-\mathrm{wr} \\
\text { errochron }\left(\mathrm{Sr}_{\mathrm{i}} 0.7030 \pm 0.0004\right)\end{array}$ & Tonalites-trondhjemites & Ign. crystallization & $\begin{array}{l}\text { Undeformed tonalitic to } \\
\text { trondhjemitic (micro-granitoid } \\
\text { enclave) pluton. No country rock } \\
\text { exposed. Continental magmatic } \\
\text { arc. [22] }\end{array}$ \\
\hline & $\begin{array}{l}1188 \pm 47 \mathrm{Ma}-\mathrm{Sm} / \mathrm{Nd}- \\
\text { wr-amph isochron } \\
T_{\mathrm{DM}} 1551-1604 \mathrm{Ma}-\mathrm{Sm} / \mathrm{Nd} \\
-\mathrm{wr}\left(\epsilon \mathrm{Nd}_{1200}+1.6 \text { to }+1.8\right)\end{array}$ & Tonalites-trondhjemites & Ign. crystallization & \\
\hline & $\begin{array}{l}869 \pm 17 \mathrm{Ma}-\mathrm{K} / \mathrm{Ar}-\mathrm{amph} \\
{[22]}\end{array}$ & Tonalite & $?$ & \\
\hline & $\begin{array}{l}810 \pm 5,763 \pm 25 \\
740 \pm 30 \mathrm{Ma}, \\
\mathrm{K} / \mathrm{Ar}-\mathrm{amph} \\
690 \pm 20 \mathrm{Ma}-\mathrm{K} / \mathrm{Ar}-\mathrm{wr} \\
392 \pm 15,382 \pm 15 \mathrm{Ma}-\mathrm{K} / \mathrm{Ar} \\
- \text { wr }[23]\end{array}$ & $\begin{array}{l}\text { Tonalite } \\
\text { Trondhjemite }\end{array}$ & & \\
\hline
\end{tabular}

\footnotetext{
${ }^{\text {a }}$ Method: $w r=$ whole rock; amph $=$ amphibole.
}

Grenvillian-age rocks, but do not have clear age constraints yet.

The Precordillera. The Precordillera is a morphostructural unit mainly composed of Paleozoic sedimentary rocks involved in a fold-and-thrust belt during the Tertiary Andean orogeny. Within this unit, the Cambro-Ordovician carbonate rocks are exposed through all the eastern part (Fig. 1). The basement rocks appear only as xenoliths within Tertiary volcanics (Leveratto, 1968), comprising mafic amphibolitic schists and biotite-bearing acidic gneisses, mafic pyroxene granulite, and pyroxene-garnet granulite gneisses. The studies of Abruzzi et al. (1993) and Mahlburg Kay et al. (1996) allowed the recognition of igneous crystallization $\mathrm{U}-\mathrm{Pb}$ ages of amphibolites and gneisses at $1118 \pm 54 \mathrm{Ma}$ and $1102 \pm 6 \mathrm{Ma}$, as well as a ${ }^{207} \mathrm{~Pb} /{ }^{206} \mathrm{~Pb}$ metamorphism ages younger than about $1083 \mathrm{Ma}$ for a mafic granulite. Meso-Proterozoic $\mathrm{Sm}-\mathrm{Nd} T_{\mathrm{DM}}$ ages as well as the depleted signatures of $\mathrm{Pb}$ isotopic ratios are comparable to those of the North American Grenville Province (Mahlburg Kay et al., 1996). The proposed tectonic environment based on geochemical data is an oceanic arc/back arc setting near a continental margin.

Frontal Cordillera. In the Cordón del Portillo, the basement rocks crop out in the southern part, around $33^{\circ} \mathrm{S}$. These low- to medium-grade metamorphic rocks (Caminos, 1993; Vujovich, 1998) comprise para- and orthogneisses, amphibolites, and marbles. The $\mathrm{U}-\mathrm{Pb}$ age of $1069 \pm 36 \mathrm{Ma}$ (Ramos and Basei, 1997) determined in prismatic igneous zircons would represent a crystallization age for the protolith of the gneisses. Sm-Nd $T_{\mathrm{DM}}$ ages calculated for other schists and gneisses are between 1427 and $1734 \mathrm{Ma}$ (Basei et al., 1998; Basei et al., unpublished data), which are similar to those obtained from the Precordillera by Mahlburg Kay et al. (1996).

San Rafael Block. The basement rocks of the Cerro La Ventana Formation (Criado Roqué, 1972), or La Ventana 

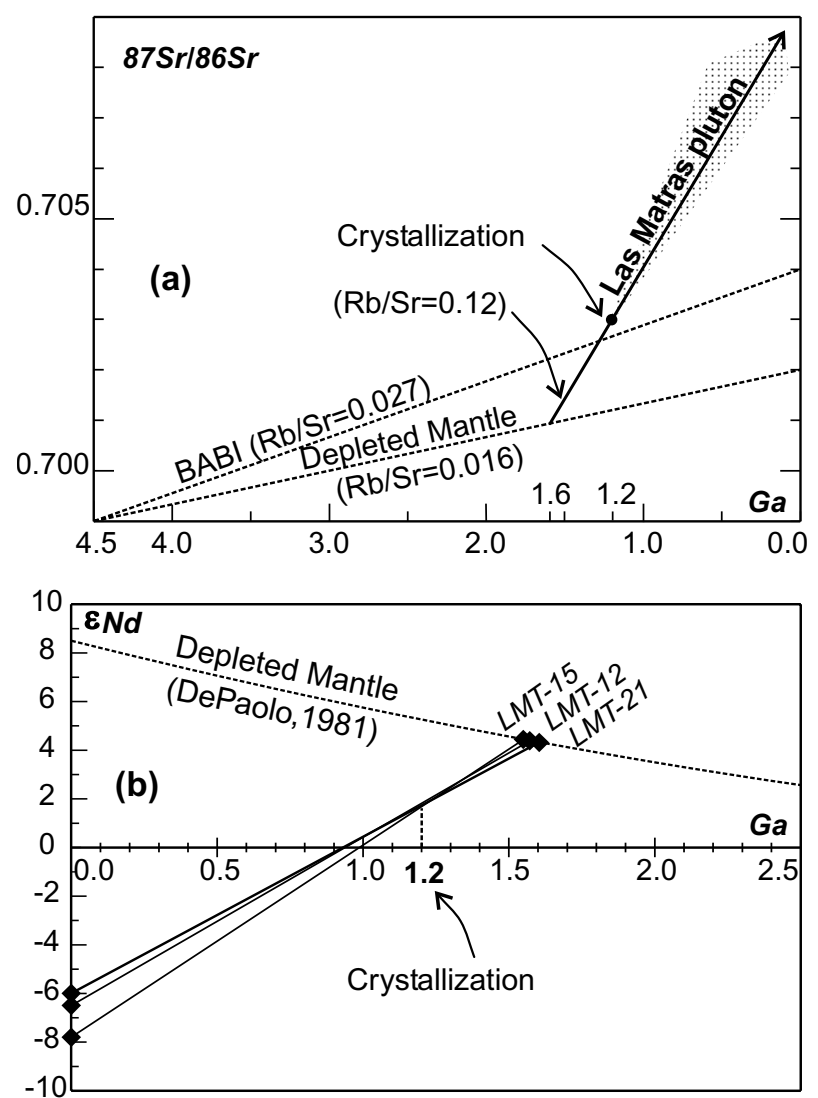

Fig. 9. (a) Linear ${ }^{87} \mathrm{Sr} /{ }^{86} \mathrm{Sr}$ evolutions of $\mathrm{BABI}$ and a depleted mantle through time; $\mathrm{Rb} / \mathrm{Sr}$ data taken from Faure (1986). Although the initial ${ }^{87} \mathrm{Sr} /{ }^{86} \mathrm{Sr}$ found for Las Matras $(0.7030)$ could be explained as a direct derivation from a normal mantle represented by BABI $(\mathrm{Rb} / \mathrm{Sr}=0.027)$ at $1.2 \mathrm{Ga}\left({ }^{87} \mathrm{Sr} /{ }^{86} \mathrm{Sr} 0.7028\right)$, it also can be explained as a refusion of a magma (having $\mathrm{Rb} / \mathrm{Sr}=0.12)$ extracted from a depleted mantle $(\mathrm{Rb} / \mathrm{Sr}=0.016)$ at $1.6 \mathrm{Ga}$. The range of $\mathrm{Rb} / \mathrm{Sr}$ found in the pluton $(0.11-0.39)$ is represented by the dotted area. This Sr-depleted mantle model age of $1.6 \mathrm{Ga}$ coincides well with the Nd $T_{\mathrm{DM}}$ model ages calculated after DePaolo (1981), which are between 1.57 and $1.61 \mathrm{Ga}(\mathrm{b})$. The $\epsilon \mathrm{Nd}_{(1200)}$ values for the moment of crystallization are between +1.67 and +1.81 , indicating a source less evolved than CHUR.

Formation (Núñez, 1979), crop out in the area of Ponon Trehue in a NNW-SSE trending belt $10 \mathrm{~km}$ long by $2 \mathrm{~km}$ wide. They consist of amphibolites and mylonitized acidic orthogneisses, micaschists, and migmatites as well as acidic to intermediate granitoids and pegmatitic and aplitic veins (Núñez, 1979; Criado Roqué and Ibáñez, 1979). According to the petrographic description of Núñez (1979), all these rocks show evidence of ductile deformation. Similar rocks were also localized in some wells (Criado Roqué and Ibáñez, 1979) to the southeast. Astini et al. (1996) cited an unpublished $\mathrm{U}-\mathrm{Pb}$ date by Bowring et al. that yielded a Grenvillian age for these rocks. Furthermore, a $\mathrm{Rb}-\mathrm{Sr}$ whole-rock isochron constructed from 7 samples of granodioritic to tonalitic rocks, which are exposed as $5 \mathrm{~m}$ long lenses parallel to the foliation of the metamorphic rocks, also yielded a Grenvillian age of $1063 \pm 106 \mathrm{Ma}$ (Cingolani and Varela, 1999). These basement rocks of the Ponon Trehue area are overlain by Ordovician fossiliferous sand- stones, slates, and limestones (Lindero Formation of Núñez, 1979; Ponon Trehue Formation of Criado Roqué and Ibáñez, 1979). These were initially correlated with the limestones mentioned from the Las Matras Block (Wichmann, 1928) and also with the Ordovician carbonate platform of the Precordillera (Bordonaro et al., 1996).

A summary of the Grenvillian ages, isotopic signatures, and Neoproterozoic dates from this belt with Grenvillianage rocks is shown in Fig. 10.

Within the above context, the low-Al tonalitic-trondhjemitic pluton at Las Matras, characterizing a magmatic arc with an age of $\sim 1200 \mathrm{Ma}$, allows its inclusion at the southern extension of the belt with Grenvillian-age rocks of central western Argentina. Along its length of almost $900 \mathrm{~km}$ (see Fig. 1), it comprises tectonic environments of continental magmatic arcs, backarcs, or oceanic arcs/back arcs near a continental margin. However, the undeformed Las Matras pluton contrasts with the medium- to high-grade metamorphic units to the north (orthogneises, amphibolites, granulites, schists, gneises, migmatites, etc). This difference is even more remarkable if we consider that the age of the pluton $(1200 \mathrm{Ma})$ is older than those $\mathrm{U}-\mathrm{Pb}, \mathrm{Pb}-\mathrm{Pb}$, and $\mathrm{Rb}-\mathrm{Sr}$ dates reported from the Western Sierras Pampeanas, Precordillera, Cordillera Frontal, and San Rafael Block. There, as summarized in Table 3 , the $\mathrm{U}-\mathrm{Pb}$ igneous crystallization ages are between $1118 \pm 54 \mathrm{Ma}$ and $1069 \pm 36 \mathrm{Ma}$, and the $\mathrm{U}-\mathrm{Pb}, \mathrm{Pb}-\mathrm{Pb}$, and $\mathrm{Rb}-\mathrm{Sr}$ metamorphism ages are between $<1083 \mathrm{Ma}$ and up to $1021 \pm 12$ Ma.

The apparent lack of overprints by regional metamorphism and ductile deformation at Las Matras should imply that this area remained unaffected or, alternatively, protected from further orogenic processes. The geological relationship with respect to the garnet-bearing schist dated at $605 \mathrm{Ma}$ (Criado Roqué, 1979), and located only $70 \mathrm{~km}$ to the north of Las Matras, is not yet clear.

On the other hand, the $\mathrm{Sm}-\mathrm{Nd}$ model ages obtained from Las Matras (1551-1604 Ma) are partially consistent with the data obtained from the Cordillera Frontal (Basei et al., 1998) and Precordillera (Mahlburg Kay et al., 1996). The low initial ${ }^{87} \mathrm{Sr} /{ }^{86} \mathrm{Sr}$ ratio of the Las Matras pluton (0.7030) is also a characteristic feature of the deformed granodioritic to tonalitic rocks of the San Rafael Block (0.7032, Cingolani and Varela, 1999) and of the orthogneiss of Sierra de Umango (0.7026, Varela et al., 1996). These are in agreement with the depleted character of the magmas involved.

With respect to the K-Ar date of 690-869 Ma obtained from the Las Matras pluton, no geological evidence can explain an isotopic resetting during Neoproterozoic times. However, other similar $\mathrm{K}-\mathrm{Ar}$ dates were mentioned from the Sierra de Valle Fértil by Toubes Spinelli (1983) for pegmatites (587-750 Ma), tonalitic gneisses (603 and $660 \mathrm{Ma})$, and an amphibolite (800 $\pm 50 \mathrm{Ma})$ whose geological meanings are difficult to appraise. Other examples are the $\mathrm{K}-\mathrm{Ar}$ date of $635 \pm 95 \mathrm{Ma}$ (amphibole of amphibolite, Linares and Aparicio, 1976), and the Ar/Ar total gas age of 


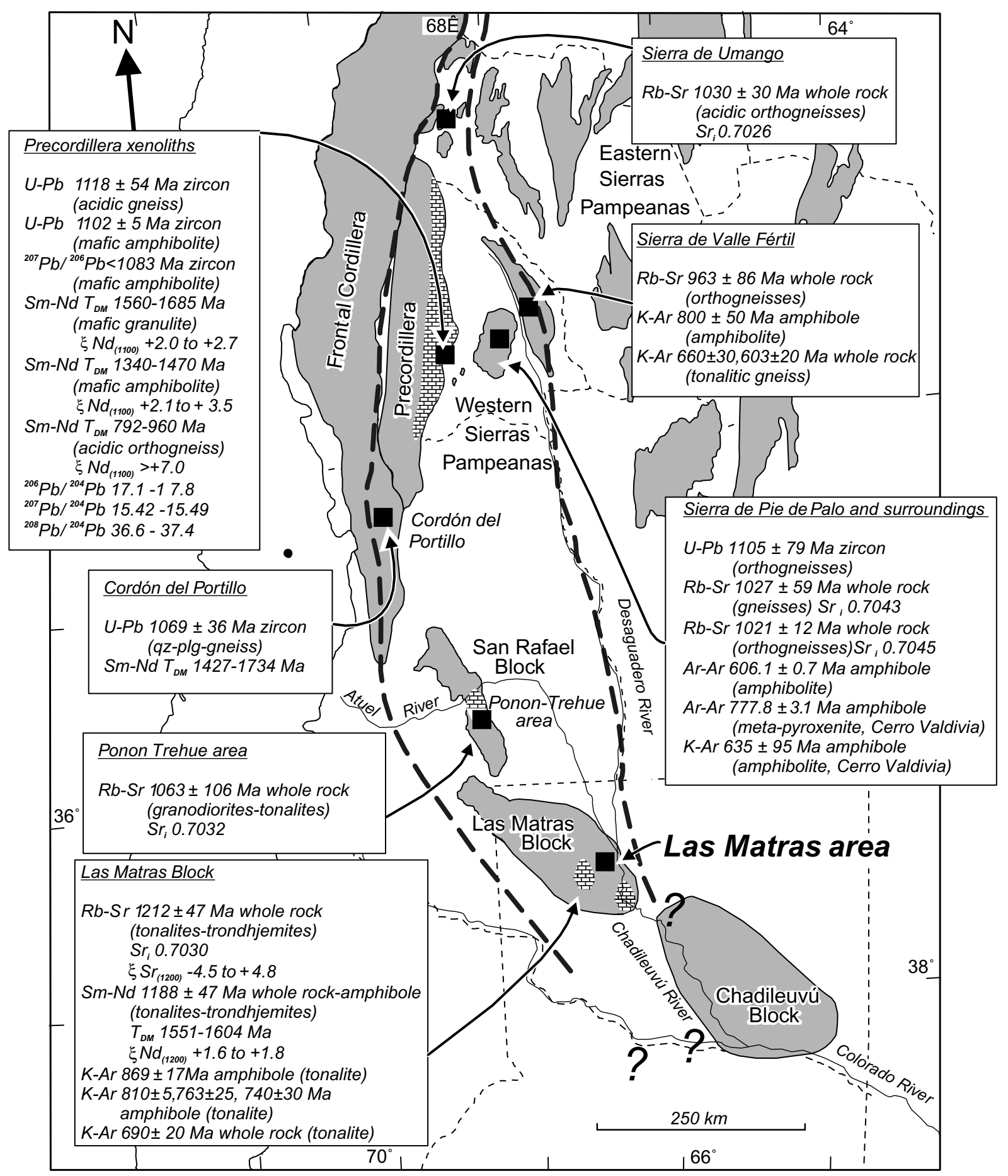

Fig. 10. Summary of the Grenvillian age constraints, isotopic signatures, and Neoproterozoic dates from the "belt with Grenvillian-age rocks" in central western Argentina, based on the general map shown in Fig. 1 and data given in Table 3. The igneous crystallization age obtained for the Las Matras pluton (ca. $1200 \mathrm{Ma})$ and its non-deformed character contrasts with the crystallization ages $(1118 \pm 54-1069 \pm 36 \mathrm{Ma})$ and metamorphism ages $(<1083-$ $1021 \pm 12 \mathrm{Ma}$ ) found for rocks to the north. This can suggest a non-homogeneous tectonic evolution for the entire belt. The low initial ${ }^{87} \mathrm{Sr} /{ }^{86} \mathrm{Sr}$ values and the available $\mathrm{Sm}-\mathrm{Nd}$ model ages are consistent throughout the belt.

777.8, approaching $1050 \mathrm{Ma}$ (hornblende of meta-pyroxenite, Ramos et al., 1998) at Cerro Valdivia south of Sierra de Pie de Palo. The main deformational ages at Sierra de Pie de Palo, Cerro Barbosa, and Valdivia, and also the Sierra de Valle Fértil-Sierra de la Huerta, are within Early Paleozoic times
(Linares and Aparicio, 1976; Toubes Spinelli, 1983; Ramos et al., 1998; Pontoriero and Castro de Machuca, 1999). These Early Paleozoic ages are considered to represent the cooling and uplift after the complex deformational events associated with the docking of the Cuyania 


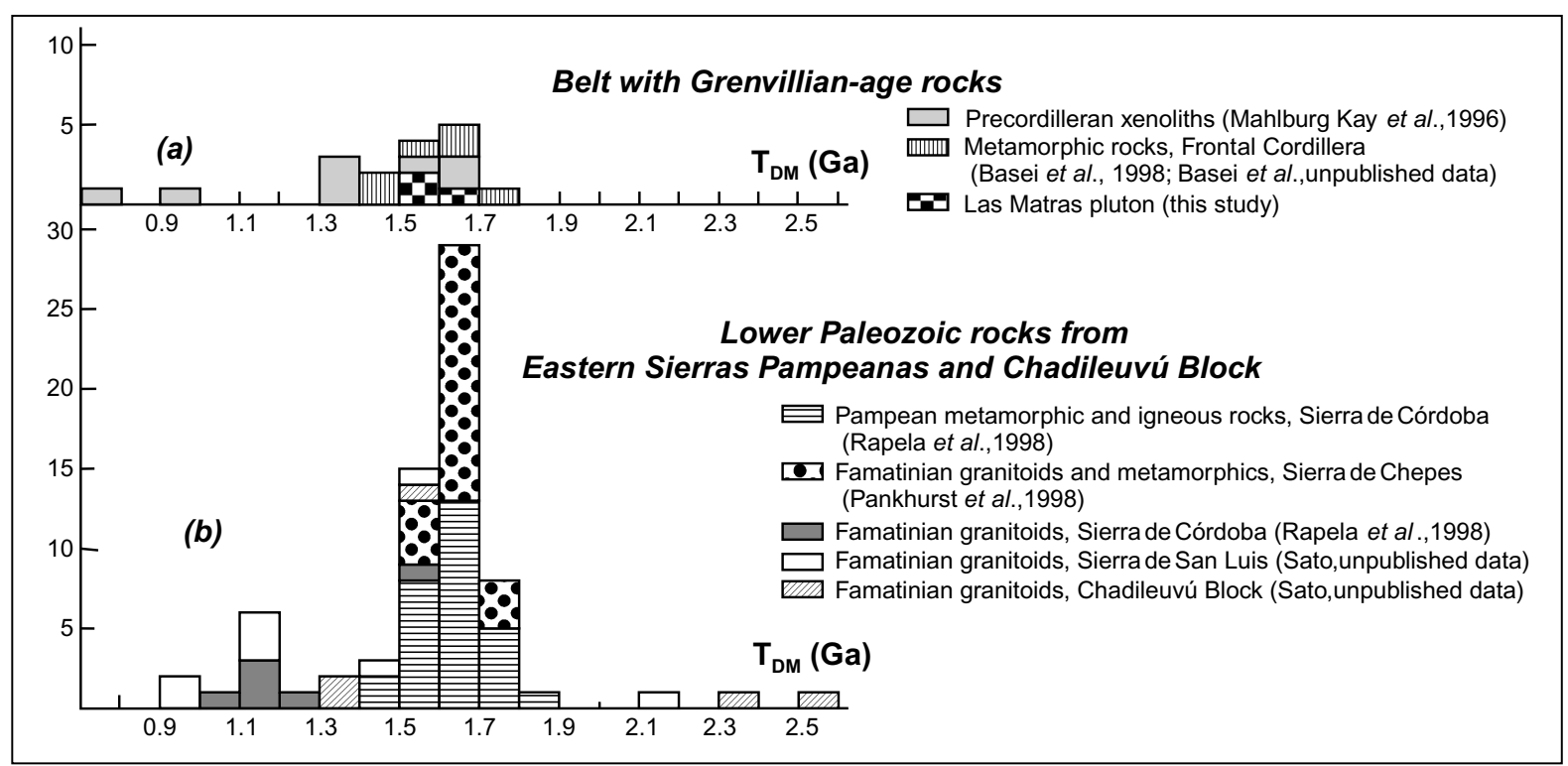

Fig. 11. $T_{\mathrm{DM}}$ model age histograms for: (a) the Grenvillian-age basement rocks (17 samples); and (b) the Early Paleozoic basement rocks from the Eastern Sierras Pampeanas and the Chadileuvú Block (70 samples). Although the orogenic cycles involved in these two parallel belts are different, the compiled $T_{\mathrm{DM}}$ data do not suggest, up to now, a clear separation of the lower crustal compositions of both belts. Only some few Paleoproterozoic data are remarkable in the Eastern Sierras Pampeanas and the Chadileuvú Block, which are not seen in the Grenvillian-age rocks.

(mid-Ordovician to Silurian) and Chilenia (Devonian) terranes at the proto-margin of Gondwana (Ramos et al., 1998). Other examples of Neoproterozoic K-Ar dates have been reported by Linares et al. (1980) and Criado Roqué (1979) within the La Pampa Province. For all the Neoproterozoic dates, no geological explanation could be found up to now.

\section{Regional implications}

The association of Grenvillian-age rocks with CambroOrdovician platform carbonates is the most characteristic feature of the Laurentian-derived Precordillera or Cuyania terrane. This rock association is clearly observed in the Precordillera $\left(29-33^{\circ} \mathrm{S}\right)$ and the San Rafael Block $\left(35^{\circ} \mathrm{S}\right)$. In the Las Matras Block, the Grenvillian-age basement rocks are also spatially associated with the recently dated Cambro-Ordovician carbonates of the San Jorge Formation. Consequently, we confirm the southern extension of the Precordillera or Cuyania terrane up to the latitudes of exposures of the San Jorge Formation $\left(37^{\circ} 15^{\prime} \mathrm{S}\right)$, as also stated by Melchor et al. (1999b) and originally suggested by Ramos (1995) and Astini et al. (1995).

To the east of and parallel to this belt of the Laurentiaderived terrane are located the Eastern Sierras Pampeanas (Sistema de Famatina, Sierras de los Llanos-MalanzánChepes, Sierra de San Luis, Sierra de Córdoba) and the Chadileuvú Block (Fig. 1). This belt of basement rocks is characterized by major orogenies of Late Proterozoic to Early Paleozoic times, successively developed during the Pampean (Late Proterozoic-Early Cambrian) and Famati- nian (Late Cambrian-Devonian) cycles. Particularly, the Famatinian orogeny is considered to be the result of the collision of the Grenvillian basement terrane to the southwestern margin of Gondwana (e.g., Dalla Salda et al., 1998; Ramos et al., 1998). Igneous rocks emplaced during these times and the associated metamorphic rocks (Linares et al., 1980; Sato et al., 1996; Llambías et al., 1998; Pankhurst and Rapela, 1998; Pankhurst et al., 1998; Rapela et al., 1998b; Saavedra et al., 1998; Sims et al., 1998; von Gosen and Prozzi, 1998; Tickyj, 1999; Tickyj et al., 1999a, among others) indicate the location of the magmatic arc. The available $\mathrm{Sm}-\mathrm{Nd}$ data indicate a very consistent Mesoproterozoic lower crust ( $T_{\mathrm{DM}} 1541-1725 \mathrm{Ma}, 21$ samples) for the Ordovician granitoids of Sierras de los Llanos-Malanzán and Chepes (Pankhurst et al., 1998). The Early Cambrian to Ordovician metamorphic rocks and granitoids of the Sierras de Córdoba also yielded a consistent group of $T_{\mathrm{DM}}$ between 1477 and $1822 \mathrm{Ma}$, with the exception of the late high-Na suite with 1069-1573 Ma (Rapela et al., 1998b). The sparse data from the Early Paleozoic granitoids of Sierra de San Luis (8 samples: Sato, unpublished data) show scattered Paleoproterozoic ( $\sim 2200 \mathrm{Ma})$ and Mesoto Neoproterozoic (1525-958 Ma) model ages. In the Chadileuvú Block, the Upper Cambrian to Ordovician granitoids (5 samples analyzed: Sato, unpublished data) are grouped in the Paleoproterozoic (2524 and $2358 \mathrm{Ma}$ ) and Mesoproterozoic (1517-1371 Ma). All these model ages, most frequently within the Mesoproterozoic, cannot be clearly distinguished from those found in the belt with Grenvillian-age rocks. In the Eastern Sierras Pampeanas and Chcadileuvú Block, only a few older (Paleoproterozoic) components are identified within the lower crust (Fig. 11). 


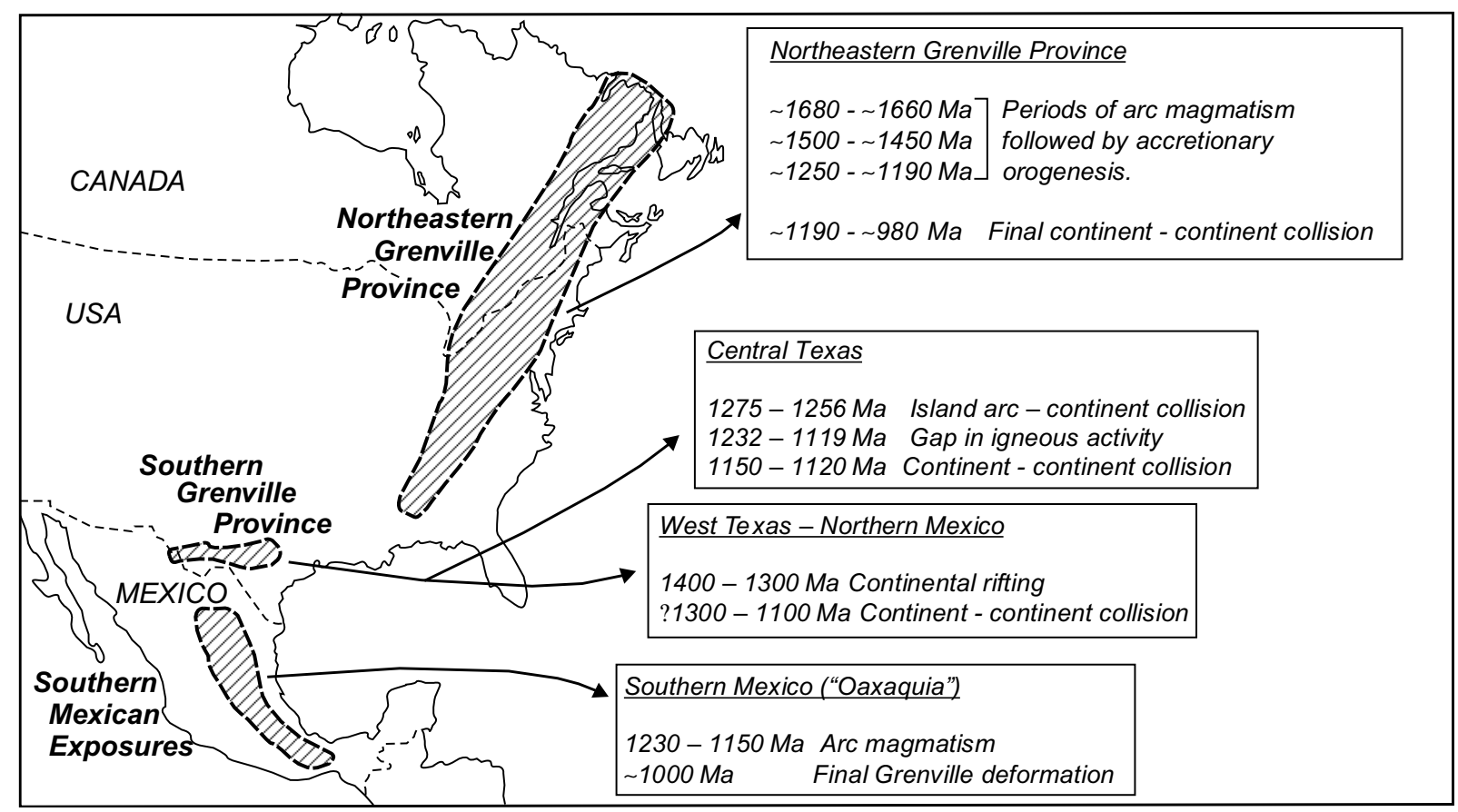

Fig. 12. Location map of the North American Grenville Provinces, compiled after Ruiz et al. (1988) and Mosher (1998). Data used for the summaries shown in each region are from the references given here. Northeastern Grenville Province: Rivers (1997), Martignole and Friedman (1998) and Corrigan et al. (2000). Southern Grenville Province (central and west Texas into northern Mexico): Mosher (1998) and Rougvie et al. (1999). Southern Mexico: Patchett and Ruiz (1987), Ruiz et al. (1988), Lawlor et al. (1999) and Weber and Köhler (1999). The "belt with Grenvillian-age rocks" of Argentina does not fit with any of these regions; however, the Early Paleozoic sedimentary cover correlation suggests the Southern Grenville Province as detachment site for the basement of the Precordillera or Cuyania terrane. Therefore, a possible independent evolution of the Argentine belt can be inferred, prior to the final amalgamation of the Laurentian Grenville orogen.

Within the belt with Grenvillian-age rocks, the effects of the Famatinian orogeny are traced through very scarce intrusive rocks of Early Paleozoic up to earliest Carboniferous ages (Western Sierras Pampeanas), and tectonic and metamorphic overprints resulting in isotopic resettings (Linares and Aparicio, 1976; Toubes Spinelli, 1983; Varela and Dalla Salda, 1992; Cingolani et al., 1993; Ramos et al., 1996; 1998; Varela et al., 1996; Pontoriero and Castro de Machuca, 1999). This influence of the Famatinian tectonics seems to diminish toward the south, as can be seen at the San Rafael Block and the Las Matras Block where no thermal overprint of these ages has been reported up to now. Perhaps only the lowgrade metamorphism and ductile deformation associated partially with the limestones of the San Jorge Formation (Melchor et al., 1999c; Tickyj, 1999) could have occurred during this period, although the timing is not yet precisely constrained.

The continuity of the western allochthonous Precordillera or Cuyania terrane and the eastern autochthonous Famatinian magmatic arc south of the Colorado River within Patagonia is not yet well known. As a first approach, the existence of metamorphic rocks of variable grades, with dates between the Neoproterozoic and Cambrian and intruded by Ordovician granitoids (Ramos, 1975; Giacosa, 1997; Varela et al., 1997; 1998), indicate the possibility that the Atlantic area of the North Patagonian Massif represents the southern extension of the Eastern Sierras Pampeanas and Chadileuvú Block (Tickyj, 1999). Nevertheless, these correlations are not yet well documented. On the other hand, the southern continuity of the Grenvillian-age rocks has not been proved up to now. The preliminary $\mathrm{Rb}-\mathrm{Sr}$ date of $850 \pm 50 \mathrm{Ma}$ reported from the Mina Gonzalito gneiss in the North Patagonian Massif (Linares et al., 1990) was later invalidated by another $\mathrm{U}-\mathrm{Pb}$ date of $526 \mathrm{Ma}$ (Varela et al., 1998). In the western region of the North Patagonian Massif, preliminary ages, $\mathrm{Rb}-\mathrm{Sr}$ isochrons and errorchrons of up to $860 \mathrm{Ma}$ (Parica, 1986; Dalla Salda et al., 1991a,b), or even the $\mathrm{Rb}-\mathrm{Sr}$ reference isochron of $1190 \pm 16 \mathrm{Ma}$ (Linares et al., 1988) could not be confirmed by other methods like U$\mathrm{Pb}$, which yielded Late Paleozoic dates (Basei et al., 1999; Varela et al., 1999).

As a result, the possible alternatives to the continuity of the Grenvillian-age rocks south of the Colorado River are: (1) that the Las Matras pluton is the southernmost outcrop of this belt and the basement does not continue southwards; (2) that the basement does continue to the south but is now displaced along a transcurrent fault zone. For the latter alternative, the Colorado River itself can represent the location. The area of Las Matras, however, should have remained protected from deformation events through the entire Proterozoic to Phanerozoic period. 


\section{Comparisons with the North American Grenville Provinces}

The Laurentian derivation of the Precordillera or Cuyania terrane was proposed based on the correlations of the Early Paleozoic lithology, biostratigraphy, paleogeography, and paleomagnetism. Within the North American Appalachian orogen, the southern area of the Ouachita embayment was pointed out as the probable detachment site for the Argentine Precordillera (Dalla Salda et al., 1992b; 1998; Astini et al., 1995; Keller and Dickerson, 1996; Dickerson and Keller, 1998; Rapalini and Astini, 1998; Thomas and Astini, 1999).

The possible source areas for the Argentine belt with Grenvillian-age rocks are then restricted to the surroundings of the Southern Grenville Province (Texas and northern Mexico), according to the source area for the Precordilleran Lower Paleozoic rocks. This rules out the Northeastern Grenville Province as a source (Fig. 12).

For this Southern Grenville Province, Mosher (1998) summarized the tectonic evolution of the Grenville orogenic belt. According to that study, the $>300 \mathrm{Ma}$ orogenic activity in central Texas comprises island arc-continent collision $(1275-1256 \mathrm{Ma})$, followed by a gap in igneous activity (1232-1119 Ma), and a continent-continent collision (1150-1120 Ma), causing polyphase deformation and high-P metamorphism. In western Texas (and northern Mexico), after a continental rifting (1400-1300 Ma), similar continent-continent collision that caused polyphase deformation was unconstrained between 1300 and $1100 \mathrm{Ma}$. Within these evolutions, all the involved rocks are deformed except the northernmost foreland regions of the orogen (north of the Llano or Grenville Front: Soegaard and Callahan, 1994) and the post-tectonic, high-K anorogenic granitoids (e.g. Red Bluff and Enchanted Rock granites: Smith et al., 1997) younger than $1120 \mathrm{Ma}$. The post-metamorphic cooling history was traced between 1100 and $1000 \mathrm{Ma}$ based on $\mathrm{U}-\mathrm{Pb}, \mathrm{Rb}-\mathrm{Sr}$, and $\mathrm{Ar}-\mathrm{Ar}$ determinations (Rougvie et al., 1999).

Comparing the above evolution of the Southern Grenville Province with the Argentine exposures, the time for crystallization of the Las Matras pluton (around $1200 \mathrm{Ma}$ ) corresponds to a time with no record of magmatism in the Southern Grenville Province. In addition, the ranges of igneous crystallization $(1118 \pm 54-1069 \pm 36 \mathrm{Ma})$ and metamorphism ages (1083-1021 $\pm 12 \mathrm{Ma}$ ) obtained from the Argentine rocks other than Las Matras pluton also correspond to a post-collisional, not deformational time of the Southern Grenville Province. These differences suggest that, up to now, a direct correlation of the Grenvillian rocks of the Southern Grenville Province with the Argentine belt has not been possible. Only a general correlation of tectonic environments, comprising oceanic arc/back arc complexes near a continental margin (Vujovich and Kay, $1996 ; 1998)$ or a continental or island magmatic arc (Castro de Machuca et al., 1996a,b; Vujovich and Kay, 1996;
Vujovich et al., 1996; this study), and the depleted $\mathrm{Pb} / \mathrm{Pb}$ or Sm/Nd signatures (Mahlburg Kay et al., 1996; Basei et al., 1998; Patchett and Ruiz, 1989; additional data in Mosher, 1998) can be established. On the other hand, few examples of trondhjemitic rocks found within the evolution of the Grenville orogeny are of high-Al character; apparently, these are younger than the Las Matras pluton, as in Cerro del Carrizarillo and Sierra del Cuervo, México (1080 \pm 5 Ma: in Mosher, 1998) or also in the Northeastern Grenville Province of the Adirondack Highlands ( 1060 Ma: Daly and McLelland, 1991).

The general tectonic evolution of the Northeastern Grenville Province (reviewed by Rivers, 1997; additional data from Corrigan et al., 2000), which developed upon the Archean to Paleoproterozoic crust, is characterized by more than 400 million years of active margin tectonism, comprising subduction/accretion and arc/back arc settings. Major juvenile crustal additions and substantial growth of the Laurentian margin occurred during different periods, which comprise arc magmatism followed by accretionary orogenesis $(\sim 1680$ to $\sim 1660 \mathrm{Ma}, \sim 1500$ to $\sim 1450 \mathrm{Ma}$, and $\sim 1250$ to $\sim 1190 \mathrm{Ma})$. The final continent-continent collision associated with the Grenvillian Orogeny is registered between $\sim 1190$ to $\sim 980 \mathrm{Ma}$, including three distinct pulses of crustal shortening separated by periods of extension and emplacement of mafic magmas and anorthosite complexes. The last stages of terrane assembly (major shear zone movements) were constrained at around $1000 \mathrm{Ma}$ (Martignole and Friedman, 1998), and the subsequent extensional regime lasted until $\sim 900 \mathrm{Ma}$ (Busch et al., 1997).

For this Northeastern Grenville Province, again it is noticeable that the period of 1230-1190 Ma (coinciding with the timing of crystallization of the Las Matras pluton) was a time of cessation of subduction-related magmatism that culminated with a back arc closure (Rivers, 1997). The general juvenile character of magmas (Daly and McLelland, 1991; McLelland et al., 1993; Rivers, 1997) is a constant feature of the entire province.

Another alternative for the source area of the Argentine belt with Grenvillian age rocks is the southwesternmost region of the Grenville Provinces in southern Mexico. There, the different rock exposures have been included in the "Oaxaquia" microcontinent (Ortega-Gutiérrez et al., 1995). The rocks comprise metagranites, amphibolites, mafic and intermediate orthogneisses, paragneisses, marbles, and metaquartzites, that underwent granulite facies metamorphism associated with minor magmatism during the final Grenville deformation at around $1000 \mathrm{Ma}$ (Ruiz et al., 1988; Lawlor et al., 1999; Weber and Köhler, 1999). Among these exposures, a felsic orthogneiss of the Guichicovi Complex yielded a crystallization age for the granitic protolith of $1231 \pm 43 \mathrm{Ma}$ and a peak granulite metamorphism age of $975 \pm 35 \mathrm{Ma}$ (U-Pb zircon: Weber and Köhler, 1999) from the Maya terrane. In the area of Novillo, the Huiznopala gneiss records an arc magmatism 
extending from $\sim 1200$ to $1150 \mathrm{Ma}$ (various $\mathrm{U}-\mathrm{Pb}$ dates). A later granulite facies metamorphism was probably associated with the emplacement of an anorthosite-gabbro complex at $\sim 1000 \mathrm{Ma}$ (Lawlor et al., 1999; Weber and Köhler, 1999). Post-metamorphic, Sm-Nd garnet ages of $\sim 933$ to $\sim 911 \mathrm{Ma}$ and $\mathrm{Rb}-\mathrm{Sr}$ biotite ages of $\sim 882$ to $\sim 866 \mathrm{Ma}$ (Weber and Köhler, 1999), as well as $\mathrm{Rb}-\mathrm{Sr}$ biotite ages of 876 and $827 \mathrm{Ma}$ (Patchett and Ruiz, 1987), are reported. The $\mathrm{Sm}-\mathrm{Nd}$ isotopic features indicate depleted-mantle model ages of $1.4-1.6 \mathrm{Ga}$ for the metaigneous rocks of all the southern Mexico exposures (Patchett and Ruiz, 1987; Ruiz et al., 1988; Lawlor et al., 1999; Weber and Köhler, 1999). The $\mathrm{Pb} / \mathrm{Pb}$ isotopic signatures are also depleted ones, similar to those reported from the Northeastern Grenville Province (Lawlor et al., 1999, and references therein).

The recognition of an arc magmatism at $\sim 1200 \mathrm{Ma}$ in the southern Mexico Grenville exposures appears to be a distinctive feature within the North American Grenville Provinces, and this age is similar to that found in the Las Matras pluton. Although this magmatic arc registers a later granulite facies deformation, it seems to be the only region with comparable $\sim 1200$ Ma magmatism like in Las Matras. The final Grenville metamorphism and deformation at around $1000 \mathrm{Ma}$ in southern Mexico is younger than in the Texas-northern Mexico region where the latest metamorphism took place at around $1150-1120 \mathrm{Ma}$. The metamorphism ages recorded from the Argentine belt with Grenvillian age rocks (1083-1021 Ma) are intermediate between those two regions. The abundant $\mathrm{Sm}-\mathrm{Nd}$ and $\mathrm{Rb}-\mathrm{Sr}$ cooling dates up to $\sim 827 \mathrm{Ma}$ reported from southern Mexico cannot be directly compared with the $\mathrm{K}-\mathrm{Ar}$ dates (869-690 Ma) of the Las Matras area, because the latter area did not record a deformation and metamorphic history.

Based on the above comparisons of magmatic and metamorphic events, the Argentine belt with Grenvillian-age rocks does not fit completely with any of the North American Grenville Provinces, showing little more similarity with the southern Mexican exposures (the $\sim 1200 \mathrm{Ma}$ magmatic arc) than with the northern Mexico-Texas region (Southern Grenville Province). However, as mentioned above, correlation of the sedimentary cover favors the derivation from the southern area of the Ouachita embayment for the Argentine Lower Paleozoic units. Therefore, the slightly different history detected in the Argentine belt with Grenvillian-age rocks can be explained by taking into account that the North American Grenville orogeny itself is a result of accretions of various Mesoproterozoic micro-blocks and arcs separated by closed oceans (OrtegaGutiérrez et al., 1995; Ruiz et al., 1988; Rivers, 1997; Mosher, 1998). In other words, it may not be necessary to expect a completely coinciding magmatic and metamorphic history of the basement to explain a derivation from a specific site. The fact that the Mesoproterozoic history found in the Argentine belt does not fit that of the Southern Grenville Province (Texas and northern Mexico) could be due to an independent evolution of the Argentine belt before its final amalgamation to the North American Grenville orogen, and would not constitute a problem in accepting that derivation site. Furthermore, within the Argentine belt itself, the evolution seems not to be homogeneous - having the area of Las Matras an older magmatic arc that has not been deformed by later metamorphic or tectonic processes.

\section{Conclusions}

As a result of the present study, the following statements can be made:

The Las Matras pluton is a microgranitoid enclave pluton of tonalitic to trondhjemitic composition, with low-Al and medium-K characteristics, possibly associated with a magmatic arc. It is noticeable that the pluton is apparently non-metamorphosed, undeformed, with the magmatic crystallization textures being not modified.

$\mathrm{Rb}-\mathrm{Sr}$ whole-rock and $\mathrm{Sm}-\mathrm{Nd}$ whole-rock mineral isochrons are interpreted to represent the crystallization age of the pluton, at around $1200 \mathrm{Ma}$. Sr, and $\mathrm{Nd}$ isotopic signatures indicate that the magma was of depleted character, with $\epsilon \mathrm{Nd}_{(1200)}=+1.7$ to +1.8 and $\epsilon \operatorname{Sr}_{(1200)}=-5$ to +5 . Together with the geochemical data, they suggest a derivation from either a basaltic magma extracted from a depleted mantle or directly from an enriched mantle.

The Grenvillian age obtained from the Las Matras pluton allows for its inclusion within the southern extension of the belt with Grenvillian-age basement rocks that developed in central western Argentina, where the magmas show similar $\mathrm{Sr}$ and $\mathrm{Nd}$ depleted signatures.

Compared to the rocks of this belt, the most remarkable features of the Las Matras pluton are: (1) an older age of $1200 \mathrm{Ma}$; (2) the high crustal level emplacement (shallow final emplacement level of the pluton, according to preliminary data); and (3) the apparent lack of overprints of further regional metamorphic or orogenic processes.

The ages obtained from the Las Matras pluton (this study), and from the spatially associated platform carbonate deposits of the San Jorge Formation (Cambro-Ordovician: Melchor et al., 1999a) confirm that, up to now, the Las Matras Block represents the southernmost extension of the Precordillera or Cuyania terrane of Laurentian origin.

To the east of this Precordillera or Cuyania terrane, the well-known parallel belt of the Eastern Sierras Pampeanas and Chadileuvú Block is characterized by the metamorphic and magmatic processes of the Pampean to Famatinian orogenies (latest Proterozoic to Early Paleozoic).

Although the above-mentioned two parallel belts of terranes differ in the timing of their basement evolution, the available $\mathrm{Sm}-\mathrm{Nd}$ model ages (most frequently in the Mesoproterozoic) do not clearly distinguish their lower crustal compositions. Only some few older (Paleoproterozoic) and also younger (Meso- to Neoproterozoic) data characterize the Eastern Sierras Pampeanas and Chadileuvú 
Block. The continuation of these two belts of terranes farther south of the Colorado River is not yet well constrained geologically and geochronologically.

Within the North American Laurentian continent, the recognition of the source area for the Precordilleran Lower Paleozoic rocks as the southern Appalachians also restricts the possible source areas for the Argentine belt with Grenvillian-age rocks to the surroundings of the Southern Grenville Province (Texas and northern Mexico). However, comparisons of magmatic and tectonic processes involved do not suggest a direct correlation of the Argentine belt with any of the North American Grenville Provinces. This difference suggests an independent evolution for the Argentine belt (which, in addition, also comprises non-homogeneous evolutions) prior to the final Grenville amalgamation to Laurentia. The fact that the Grenville orogeny itself is the result of accretion of various microterranes and arcs support this interpretations. This, in turn, does not constitute a problem with accepting the area of the Ouachita embayment as the detachment site for the Precordillera or Cuyania terrane.

The possibilities of correlations with the coeval terranes of the Islas Malvinas (Falkland Islands: Cingolani and Varela, 1976; Thomas et al., 1998; Wareham et al., 1998; Jacobs et al., 1999), the Mesoproterozoic belt of Uruguay (Preciozzi et al., 1999), as well as the Sunsas belt of the South American Amazon Craton (Sadowski and Bettencourt, 1996; Sato and Tassinari, 1997) or the Brazilian coastal and southern regions (Sato, 1998) have not yet been clarified.

\section{Acknowledgements}

Field and laboratory work were financially supported by CONICET (grant PIP 4329/96), ANPCyT (grant PICT 0743), and UNLP. We thank S.M. Kay for helpful comments on an earlier version of the manuscript. W. von Gosen is gratefully acknowledged for discussions and constructive review of the manuscript. Discussions with V. Ramos, R. Varela, and I. Mc Reath, and the observations and suggestions of the reviewers (R. Kay and S. Poma) contributed greatly to improving the interpretations. L. Petronilho is also acknowledged for her assistance with laboratory work. We appreciate very much the unpublished $T_{\mathrm{DM}}$ data on the Frontal Cordillera provided by M. Basei and coworkers.

\section{References}

Abruzzi, J.M., Kay, S.M., Bickford, M.E., 1993. Implications for the nature of the Precordilleran basement from the geochemistry and age of Precambrian xenoliths in Miocene volcanic rocks, San juan province. XII Congreso Geológico Argentino y II Congreso de Exploración de Hidrocarburos, Actas, vol. 3, pp. 331-339.

Astini, R.A., 1998. Stratigraphical evidence supporting the rifting, drifting and collision of the laurentian Precordillera terrane of western
Argentina. In: Pankhurst, R.J., Rapela, C.W. (Eds.), The Proto-Andean Margin of Gondwana. Geological Society London, Special Publication, 142, pp. 11-33.

Astini, R., Benedetto, J., Vaccari, N., 1995. The early Palaeozoic evolution of the Argentine Precordillera as a Laurentian rifted, drifted and collided terrane, a geodynamic model. Geological Society of America Bulletin 107, 253-273.

Astini, R., Ramos, V.A., Benedetto, J., Vaccari, N., Cañas, F.L., 1996. La Precordillera: Un terreno exótico a Gondwana. XIII Congreso Geológico Argentino y III Congreso de Exploración de Hidrocarburos, Actas, vol. 5, pp. 293-324.

Barker, F., 1979. Trondhjemite: Definition, environment and hypotheses of origin. In: Barker, F. (Ed.), Trondhjemites, Dacites and Related Rocks. Developments in Petrology, vol. 6. Elsevier Scientific, Amsterdam, pp. 1-22 (IGCP Project 092; 659 pp.).

Basei, M., Ramos, V.A., Vujovich, G.I., Poma, S., 1998. El basamento metamórfico de la Cordillera Frontal de Mendoza: Nuevos datos geocronológicos e isotópicos. X Congreso Latinoamericano de Geología y VI Congreso Nacional de Geología Económica (Buenos Aires), Actas, vol. 2, pp. 412-417.

Basei, M., Brito Neves, B.B., Varela, R., Teixeira, W., Siga Jr., O., Sato, A.M., Cingolani, C.A., 1999. Isotopic dating on the crystalline basement rocks of the Bariloche region, Río Negro, Argentina. II South American Symposium on Isotope Geology (Villa Carlos Paz, Argentina), Actas, pp. 15-18.

Benedetto, J.L., 1998. Early Palaeozoic brachiopods and associated shelly faunas from western Gondwana: Their bearing on the geodynamic history of the pre-Andean margin. In: Pankhurst, R.J., Rapela, C.W. (Eds.), The Proto-Andean Margin of Gondwana. Geological Society London, Special Publication, 142, 57-83.

Bond, C.G., Nickeson, A., Kominz, M.A., 1984. Breakup of a supercontinent between $625 \mathrm{Ma}$ and $555 \mathrm{Ma}$ : New evidence and implications for continental histories. Earth and Planetary Science Letters 80, 325-345.

Bordonaro, O., Keller, M., Lehnert, O., 1996. El Ordovícico de Ponon Trehue en la provincia de Mendoza (Argentina): Redefiniciones estratigráficas. XIII Congreso Geológico Argentino y III Congreso de Exploración de Hidrocarburos, Actas, vol. 1, 541-550.

Busch, J.P., Mezger, K., van der Plujim, B.A., 1997. Suturing and extensional reactivation in the Grenville orogen, Canada. Geology 25, 507510.

Caminos, R., 1993. El basamento metamórfico proterozoico-paleozoico inferior. In: Ramos, V.A. (Ed.), Geología y Recursos Naturales de Mendoza. XII Congreso Geológico Argentino y II Congreso de Exploración de Hidrocarburos, Relatorio, 1(2), 11-19.

Castro de Machuca, B., Conte-Grand, A., Meissl, E., Pontoriero, S., Sumay, C., 1996a. Petrología de las asociaciones máficas-ultramáficas de la Sierra de la Huerta, San Juan, Argentina. XIII Congreso Geológico Argentino y III Congreso de Exploración de Hidrocarburos, Actas, vol. 3, 439-452.

Castro de Machuca, B., Pontoriero, S., Llambías, E.J., 1996b. Evidencias petrológicas y geoquímicas de la evolución de un arco magmático en la Sierra de la Huerta, provincia de San Juan. XIII Congreso Geológico Argentino y III Congreso de Exploración de Hidrocarburos, Actas, vol. 3, p. 517.

Cingolani, C.A., Varela, R., 1976. Investigaciones geológicas y geocronológicas en el extremoo sur de la isla Gran Malvina, sector de Cabo Belgrano (Cabo Meredith), Islas Malvinas. VI Congreso Geológico Argentino, Actas, vol. 1, pp. 457-473.

Cingolani, C.A., Varela, R., 1999. Rb-Sr isotopic age of basement rocks of the San Rafael Block, Mendoza, Argentina. II South American Symposium on Isotope Geology (Villa Carlos Paz, Argentina), Actas, pp. 2326.

Cingolani, C.A., Varela, R., Dalla Salda, L., Kawashita, K., 1993. Los granitoides del cerro Veladero, río de la Troya, provincia de La Rioja: Estudio geocronológico e implicancias tectónicas. XII Congreso Geológico Argentino y II Congreso de Exploración de Hidrocarburos, Actas, vol. 4, pp. 68-74. 
Criado Roqué, P., 1972. Cinturón Móvil Mendocino-Pampeano. In: Leanza, A.F. (Ed.), Geología Regional Argentina, pp. 297-303. Academia Nacional de Ciencias, Córdoba, Argentina, 869 pp.

Criado Roqué, P., 1979. Subcuenca de Alvear. II Simposio de Geología Regional Argentina (Academia Nacional de Ciencias de Córdoba), vol. $1,811-836$.

Criado Roqué, P., Ibáñez, G., 1979. Provincia Geológica SanrafaelinoPampeana. II Simposio de Geología Regional Argentina (Academia Nacional de Ciencias de Córdoba), vol. 1, 837-869.

Corrigan, D., Rivers, T., Dunning, G., 2000. U-Pb constraints for the plutonic and tectonometamorphic evolution of Lake Melville terrane, Labrador, and implications for basement reworking in the northeastern Grenville Province. Precambrian Research 99, 65-90.

Dalla Salda, L.H., Varela, R., 1984. El metamorfismo en el tercio sur de la sierra de Pie de Palo, San Juan. Revista de la Asociación Geológica Argentina 39, 68-93.

Dalla Salda, L.H., Cingolani, C., Varela, R., 1991a. El basamento preandino ígneo-metamórfico de San Martín de los Andes, Neuquén. Revista de la Asociación Geológica Argentina 46, 223-234.

Dalla Salda, L.H., Cingolani, C., Varela, R., 1991b. El basamento cristalino de la región norpatagónica de los lagos Gutiérrez, Mascardi y Guillelmo, provincia de Río Negro. Revista de la Asociación Geológica Argentina 46, 263-276.

Dalla Salda, L.H., Cingolani, C., Varela, R., 1992a. Early Paleozoic orogenic belt of the Andes in southwestern South America: Result of Laurentia-Gondwana collision?. Geology 20, 617-620.

Dalla Salda, L.H., Dalziel, I., Cingolani, C., Varela, R., 1992b. Did the Taconic Appalachians continue into southern South America?. Geology 20, 1059-1062.

Dalla Salda, L.H., López de Luchi, M.G., Cingolani, C.A., Varela, R., 1998. Laurentia-Gondwana collision: The origin of the Famatinian-Appalachian Orogenic Belt (a review). In: Pankhurst, R.J., Rapela, C.W. (Eds.), The Proto-Andean Margin of Gondwana. Geological Society London, Special Publication, 142, 219-234.

Daly, J.S., McLelland, L.M., 1991. Juvenile Middle Proterozoic crust in the Adirondack Highlands, Grenville province, northeastern North America. Geology 19, 119-122.

Dalziel, I.W.S., 1997. Neoproterozoic-Palaeozoic geography and tectonics: Review, hypothesis, environmental speculation. Geological Society of America Bulletin 109, 16-42.

Dalziel, I.W.S., Dalla Salda, L.H., Gahagan, L.M., 1994. Palaeozoic Laurentia-Gondwana interaction and the origin of the Appalachian-Andean mountain systems. Geological Society of America Bulletin 106, 243252.

DePaolo, D.J., 1981. A neodymium and strontium isotopic study of the Mesozoic calc-alkaline granitic batholiths of the Sierra Nevada and Peninsular Ranges, California. Journal of Geophysical Research 86 (B11), 10 470-10 488.

Dickerson, P.W., Keller, M., 1998. The Argentine Precordillera: Its odyssey from the Laurentian Ouachita margin towards the Sierras Pampeanas of Gondwana. In: Pankhurst, R.J., Rapela, C.W. (Eds.), The ProtoAndean Margin of Gondwana. Geological Society London, Special Publication, 142, 325-341.

Drummond, M.S., Defant, M.J., 1990. A model for trondhjemite-tonalitedacite genesis and crustal growth via slab melting: Archean to modern comparisons. Journal of Geophysical Research 95 (B13), $21503-$ 21521.

Drummond, M.S., Defant, M.J., Kepezhinskas, P.K., 1996. Petrogenesis of slab-derived trondhjemite-tonalite-dacite/adakite magmas. Transactions of the Royal Society of Edinburgh: Earth Sciences 87, 205-215.

Elburg, M.A., 1996. Genetic significance of multiple enclave types in a peraluminous ignimbrite suite, Lachlan Fold Belt, Australia. Journal of Petrology 37, 1385-1408.

Elburg, M.A., Nicolls, L.A., 1995. Origin of microgranitoid enclaves in the S-type Wilson's Promontory Batholith, Victoria: Evidence for magma mingling. Australian Journal of Sciences 42, 423-435.

Faure, G., 1986. Principles of Isotope Geology. 2nd ed. Wiley, New York.
Giacosa, R., 1997. Geología y petrología de las rocas pre-cretácicas de la región de sierra Pailemán, provincia de Río Negro. Revista de la Asociación Geológica Argentina 52, 65-80.

González Díaz, E.F., García, H.H., 1968. El hallazgo del Neopaleozoico plantífero en el área de Agua Escondida (sudeste de Mendoza y noroeste de La Pampa). III Jornadas Geológicas Argentinas, Actas, vol. 1, 341-354.

Irvine, T.N., Baragar, W.R.A., 1971. A guide to the chemical classification of the common rocks. Canadian Journal of Earth Sciences 8, 523-548.

Jacobs, J., Thomas, R.J., Armstrong, R.A., Henjes-Kunst, F., 1999. Age and thermal evolution of the Mesoproterozoic Cape Meredith Complex, West Falkland. Journal of the Geological Society, London 156, $917-$ 928.

Kay, R.W., Mahlburg Kay, S., 1993. Delamination and delamination magmatism. Tectonophysics 219, 177-189.

Keller, M., Dickerson, P.W., 1996. The missing continent of Llanoria Was it the Argentine Precordillera? XIII Congreso Geológico Argentino y III Congreso de Exploración de Hidrocarburos, Actas, vol. 5, pp. 355-367.

Keller, M., Buggisch, W., Lehnert, O., 1998. The stratigraphical record of the Argentine Precordillera and its plate-tectonic background. In: Pankhurst, R.J., Rapela, C.W. (Eds.), The Proto-Andean Margin of Gondwana. Geological Society London, Special Publication, 142, pp. $34-56$.

Lawlor, P.J., Ortega-Gutiérrez, F., Cameron, K.L., Ochoa-Camarillo, H., Lopez, R., Sampson, D.E., 1999. U-Pb geochronology, geochemistry, and provenance of the Grenvillian Huiznopala gneiss of eastern Mexico. Precambrian Research 94, 73-99.

Leveratto, M.A., 1968. Geología de la zona al oeste de Ullún-Zonda, borde oriental de la Precordillera de San Juan, eruptividad subvolcánica y estructura. Revista de la Asociación Geológica Argentina 23, 129-157.

Linares, E., Aparicio, E.P., 1976. Edades potasio-argón de rocas de las Sierras Pampeanas de San Juan (Sierra de Pie de Palo, Cerro Valdivia y Cerrillos de Barbosa), República Argentina. VI Congreso Geológico Argentino, Actas, vol. 1, pp. 495-500.

Linares, E., Llambías, E.J., Latorre, C.O., 1980. Geología de la provincia de La Pampa, República Argentina, y geocronología de sus rocas metamórficas y eruptivas. Revista de la Asociación Geológica Argentina 35, 87-146.

Linares, E., Cagnoni, M., Do Campo, M., Ostera, H., 1988. Geochronology of metamorphic and eruptive rocks of southeastern Neuquen and northwestern Río Negro provinces, Argentine Republic. Journal of South American Earth Sciences 1, 53-61.

Linares, E., Ostera, H.A., Parica, C., 1990. Edades radimétricas preliminares del Basamento Cristalino de las vecindades de Mina Gonzalito y de Valcheta, Provincia de Río Negro, República Argentina. XI Congreso Geológico Argentino, Actas, vol. 2, pp. 251-254.

Llambías. E.J., 1975. Geología de la Provincia de La Pampa y su Aspecto Minero. Unpublished Report of the Dirección de Minas de la Provincia de La Pampa, Argentina, 38 pp.

Llambías, E.J., Caminos, R.L., 1987. El magmatismo neopaleozoico de Argentina. In: Archangelsky, S. (Ed.), El Sistema Carbonífero de la República Argentina, pp. 239-264. Academia Nacional de Ciencias, Córdoba, Argentina, 383 pp.

Llambías, E.J., Melchor, R.N., Tickyj, H., Sato, A.M., 1996. Geología del Bloque del Chadileuvú. XIII Congreso Geológico Argentino y III Congreso de Exploración de Hidrocarburos, Actas, vol. 5, pp. 417-425.

Llambías, E.J., Sato, A.M., Ortíz Suárez, A., Prozzi, C., 1998. The granitoids of the Sierra de San Luis. In: Pankhurst, R.J., Rapela, C.W. (Eds.), The Proto-Andean Margin of Gondwana. Geological Society London, Special Publication, 142, 325-341.

Mahlburg Kay, S.M., Orrell, S., Abbruzzi, J.M., 1996. Zircon and whole rock $\mathrm{Nd}-\mathrm{Pb}$ isotopic evidence for a Grenville age and a Laurentian origin for the basement of the Precordillera in Argentina. Journal of Geology 104, 637-648.

Martignole, J., Friedman, R., 1998. Geochronological constraints on the last 
stages of terrane assembly in the central part of the Grenville Province. Precambrian Research 92, 145-164.

Martin, H., 1986. Effect of steeper Archean geothermal gradient on geochemistry of subduction-zone magmas. Geology 14, 753-756.

Martin, H., 1987. Petrogenesis of Archaean trondhjemites, tonalites, and granodiorites from eastern Finland: Major and trace element geochemistry. Journal of Petrology 28, 921-953.

McDonough, M.R., Ramos, V.A., Isachsen, C.E., Bowring, S.A., Vujovich, G., 1993. Edades prieliminares de circones del basamento de la Sierra de Pie de Palo, Sierras Pampeanas occidentales de San Juan, sus implicancias para el supercontinente proterozoico de Rodinia. XII Congreso Geológico Argentino y II Congreso de Exploración de Hidrocarburos, Actas, vol. 3, pp. 340-342.

McLelland, J.M., Daly, J.S., Chiarenzelli, J.R., 1993. Sm-Nd and U-Pb isotopic evidence of juvenile crust in the Adirondack Lowlands and implications for the evolution of the Adirondack Mts. Journal of Geology $101,97-105$.

Melchor, R.N., 1996. La bahía Pampeana de la Cuenca San Rafael. Reunión Anual del Grupo Argentino de Trabajo del Paleozoico Superior (Buenos Aires), Comunicaciones, pp. 26-27.

Melchor, R.N., Cheng, Z., Foland, K., 1999a. Isotopic dating of San Jorge Fm. limestones (Early Paleozoic): Preliminary results from a $\mathrm{Pb} / \mathrm{Pb}$ isochron and ${ }^{87} \mathrm{Sr} /{ }^{86} \mathrm{Sr}$ ratios. II South American Symposium on Isotope Geology (Villa Carlos Paz, Argentina), Actas, pp. 414-417.

Melchor, R.N., Sato, A.M., Llambías, E.J., Tickyj, H., 1999b. Confirmación de la extensión meridional del Terreno Cuyania/Precordillera en la provincia de La Pampa, Argentina. XIV Congreso Geológico Argentino, Actas, vol. 1, pp. 156-159.

Melchor, R.N., Tickyj, H., Dimieri, L.V., 1999c. Estratigrafía, sedimentología y estructura de las calizas de la Formación San Jorge (CámbricoOrdovícico), oeste de La Pampa. XIV Congreso Geológico Argentino, Actas, vol. 1, pp. 389-392.

Mirré, J.C., 1971. Caracterización de una comarca de metamorfismo regional epizonal de alto grado: La Sierra de Valle Fértil, Provincia de San Juan, República Argentina. Revista de la Asociación Geológica Argentina 26, 113-127.

Mosher, S., 1998. Tectonic evolution of the southern Laurentian Grenville orogenic belt. Geological Society of America Bulletin 110, 1357-1375.

Núñez, E., 1979. Descripción Geológica de la Hoja 28d, Estación Soitué. Servicio Geológico Nacional, Buenos Aires, Argentina, Boletín, vol. $166,67 \mathrm{pp}$.

O’Connor, J.T., 1965. A classification for quartz-rich igneous rocks based on feldspar ratios. U.S. Geological Survey, Professional Paper, 525B, pp. $79-84$.

Ortega-Gutiérrez, F., Ruiz, J., Centeno-García, E., 1995. Oaxaquia, a Proterozoic microcontinent accreted to North America during the Late Paleozoic. Geology 23, 1127-1130.

Ortiz, A., 1967. Estudio Geológico de la Zona Occidental de La Pampa, desde La Escondida hasta Pichi Mahuida. Yacimientos Petrolíferos Fiscales, Comisión Geológica, Buenos Aires, Argentina, Report, 6, $23 \mathrm{pp}$.

Pankhurst, R.J., Rapela, C.W., 1998. The Proto-Andean margin of Gondwana: An introduction. In: Pankhurst, R.J., Rapela, C.W. (Eds.), The Proto-Andean Margin of Gondwana. Geological Society London, Special Publication, 142, 1-9.

Pankhurst, R.J., Rapela, C.W., Saavedra, J., Baldo, E., Dahlquist, J., Pascua, I., Fanning, C.M., 1998. The Famatinian magmatic arc in the central Sierras Pampeanas: An Early to mid-Ordovician continental arc on the Gondwana margin. In: Pankhurst, R.J., Rapela, C.W. (Eds.), The Proto-Andean Margin of Gondwana. Geological Society London, Special Publication, 142, 343-367.

Parica, C., 1986. Resultados geocronológicos preliminares de las Formaciones Colohuincul y Huechulafquen, provincia de Neuquén. Revista de la Asociación Geológica Argentina 41, 201-205.

Patchett, P.J., Ruiz, J., 1987. Nd isotopic ages of crust formation and metamorphism in the Precambrian of eastern and southern Mexico. Contributions to Mineralogy and Petrology 96, 523-528.
Patchett, P.J., Ruiz, J., 1989. Nd isotopes and the origin of Grenville-age rocks in Texas: Implications for Proterozoic evolution of the United States mid-continent region. Journal of Geology 97, 685-695.

Pearce, J.A., Harris, N.B.W., Tindle, A.G., 1984. Trace element discrimination diagrams for the tectonic interpretation of granitic rocks. Journal of Petrology 25, 956-983.

Pontoriero, S., Castro de Machuca, B., 1999. Contribution to the age of the igneous-metamorphic basement of the La Huerta Range, province of San Juan, Argentina. II South American Symposium on Isotope Geology (Villa Carlos Paz, Argentina), Actas, pp. 101-104.

Preciozzi, F., Masquelin, H., Stipp Basei, M.A., 1999. The Namaqua/Grenville terrane of eastern Uruguay. II South American Symposium on Isotope Geology (Villa Carlos Paz, Argentina), Actas, pp. 338-340.

Ramos, V.A., 1975. Geología del sector oriental del Macizo Nordpatagónico entre Aguada Capitán y la Mina Gonzalito, provincia de Río Negro. Revista de la Asociación Geológica Argentina 30, 274-285.

Ramos, V.A., 1995. Sudamérica: un mosaico de continentes y océanos. Ciencia Hoy (Buenos Aires) 6, 24-29.

Ramos, V.A., Basei, M.A.S., 1997. The basement of Chilenia: An exotic continental terrane to Gondwana during the Early Paleozoic. In: Terrane Dynamics-97 (Christchurch, New Zealand), Conference Abstracts, pp. 140-143.

Ramos, V.A., Jordan, T., Allmendinger, R.W., Kay, S.M., Cortés, J.M., Palma, M.A., 1984. Chilenia: Un terreno alóctono en la evolución paleozoica de los Andes Centrales. IX Congreso Geológico Argentino, Actas, vol. 2, pp. 84-106.

Ramos, V.A., Vujovich, G., Dallmeyer, R.D., 1996. Los klippes y ventanas tectónicas preándicas de la Sierra de Pie de Palo (San Juan): Edad e imiplicaciones tectónicas. XIII Congreso Geológico Argentino y III Congreso de Exploración de Hidrocarburos, Actas, vol. 5, pp. 377-391.

Ramos, V.A., Dallmeyer, R.D., Vujovich, G., 1998. Time constraints on the Early Palaeozoic docking of the Precordillera, central Argentina. In: Pankhurst, R.J., Rapela, C.W. (Eds.), The Proto-Andean Margin of Gondwana. Geological Society London, Special Publication, 142, $143-158$.

Rapalini, A.E., Astini, R.A., 1998. Paleomagnetic confirmation of the Laurentian origin of the Argentine Precordillera. Earth and Planetary Science Letters $155,1-14$.

Rapela, C.W., Pankhurst, R.J., Casquet, C., Baldo, E., Saavedra, J., Galindo, C., 1998a. Early evolution of the Proto-Andean margin of South America. Geology 26, 707-710.

Rapela, C.W., Pankhurst, R.J., Casquet, C., Baldo, E., Saavedra, J., Galindo, C., Fanning, M., 1998b. The Pampean orogeny of the southern proto-Andes: Cambrian continental collision in the Sierras de Córdoba. In: Pankhurst, R.J., Rapela, C.W. (Eds.), The Proto-Andean Margin of Gondwana. Geological Society London, Special Publication, 142, 181217.

Rivers, T., 1997. Lithotectonic elements of the Grenville Province: Review and tectonic implications. Precambrian Research 86, 117-154.

Rougvie, J.R., Carlson, W.D., Copeland, P., Connelly, J.N., 1999. Late thermal evolution of Proterozoic rocks in the northeastern Llano Uplift, central Texas. Precambrian Research 94, 49-72.

Ruiz, J., Patchett, P.J., Ortega-Gutiérrez, F., 1988. Proterozoic and Phanerozoic basement terranes of Mexico from Nd isotopic studies. Geological Society of America Bulletin 100, 274-281.

Saavedra, J., Toselli, A., Rossi, J., Pellitero, E., Durand, F., 1998. The Early Palaeozoic magmatic record of the Famatina System: A review. In: Pankhurst, R.J., Rapela, C.W. (Eds.), The Proto-Andean Margin of Gondwana. Geological Society London, Special Publication, 142, 283-295.

Sadowski, G.R., Bettencourt, J.S., 1996. Mesoproterozoic tectonic correlations between eastern Laurentia and the western border of the Amazon Craton. Precambrian Research 76, 213-217.

Sato, K., 1998. Evolução Crustal da Plataforma Sul Americana com Base na Geoquímica Sm-Nd. Unpublished PhD thesis, Instituto de Geociencias, Universidade de São Paulo, São Paulo SP, Brazil, 297 pp.

Sato, K., Tassinari, C.C.G., 1997. Principais eventos de acreção continental 
no Craton Amazônico baseados em idade modelo Sm-Nd, calculada em evoluções de estágio único e estágio duplo. In: Lima da Costa, M., Simões, R.A. (Eds.), Contribucões a Geologia da Amazonia. Sociedade Brasileira de Geociências, pp. 91-142.

Sato, K., Tassinari, C.C.G., Kawashita, K., Petronilho, L., 1995. O método geocronológico Sm-Nd no IG/USP e suas aplicações. Anais da Academia Brasileira de Ciências 67, 313-336.

Sato, A.M., Tickyj, H., Llambías, E.J., 1996. Geología de los granitoides aflorantes en el sur de la provincia de La Pampa, Argentina. XIII Congreso Geológico Argentino y III Congreso de Exploración de Hidrocarburos, Actas, vol. 5, pp. 429-439.

Sato, A.M., Tickyj, H., Llambías, E.J., 1998. Rb-Sr Grenvillian age from the Las Matras diorite, La Pampa province, Argentina. X Congreso Latinoamericano de Geología y VI Congreso Nacional de Geología Económica (Buenos Aires), Actas, vol. 2, p. 418.

Sato, A.M., Tickyj, H., Llambías, E.J., Sato, K., 1999. Rb-Sr, Sm-Nd and $\mathrm{K}-\mathrm{Ar}$ age constraints of the Grenvillian Las Matras pluton, central Argentina. II South American Symposium on Isotope Geology (Villa Carlos Paz, Argentina), Actas, pp. 122-126.

Sims, J.P., Ireland, T.R., Camacho, A., Lyons, P., Pieters, P.E., Skirrow, R.G., Stuart-Smith, P.G., Miró, R., 1998. U-Pb, Th-Pb and $\mathrm{Ar}-\mathrm{Ar}$ geochronology from the southern Sierras Pampeanas, Argentina: Implications for the Palaeozoic tectonic evolution of the western Gondwana margin. In: Pankhurst, R.J., Rapela, C.W. (Eds.), The Proto-Andean Margin of Gondwana. Geological Society London, Special Publication, 142, pp. 259-281.

Smith, D.R., Barnes, C., Shannon, W., Roback, R., James, E., 1997. Petrogenesis of mid-Proterozoic granitic magmas: Examples from central and west Texas. Precambrian Research 85, 53-79.

Soegaard, K., Callahan, D.M., 1994. Late middle Proterozoic Hazel Formation near Van Horn, trans-Pecos Texas: Evidence for transpressive deformation in Grenvillian basement. Geological Society of America Bulletin 106, 413-423.

Tickyj, H., 1999. Estructura y Petrología de Basamento en la Región Centro-Sur de la Provincia de La Pampa, Argentina. Unpublished $\mathrm{PhD}$ thesis, Universidad Nacional de La Plata, La Plata, Argentina, $228 \mathrm{pp}$.

Tickyj, H., Basei, M.A.S., Sato, A.M., Llambías, E.J., 1999a. U-Pb and KAr ages of Pichi Mahuida Group, crystalline basement of south-eastern La Pampa Province, Argentina. II South American Symposium on Isotope Geology (Villa Carlos Paz, Argentina), Actas, pp. 139-142.

Tickyj, H., Llambías, E.J., Sato, A.M., 1999b. El basamento cristalino de la región sur-oriental de la provincia de La Pampa: Extensión austral del Orógeno Famatiniano de Sierras Pampeanas. XIV Congreso Geológico Argentino, Actas, vol. 1, pp. 160-163.

Thomas, W.A., Astini, R.A., 1996. The Argentine Precordillera: A traveler from the Ouachita Embayment of North American Laurentia. Science 283, 752-757.

Thomas, W.A., Astini, R.A., 1999. Simple-shear conjugate rift margins of the Argentine Precordillera and the Ouachita embayment of Laurentia. Geological Society of America Bulletin 111, 1069-1079.

Thomas, R.J., Jacobs, J., Armstrong, R.A., Henjes-Kunst, F., 1998. Geochronology of the Mesoproterozoic Cape Meredith Complex, West Falkland: Comparisons with Natal and East Antarctica. Journal of African Earth Sciences 27 (1A), 194-196.

Toubes Spinelli, R.O., 1983. Edades potasio-argón de algunas rocas de la Sierra de Valle Fértil, provincia de San Juan. Revista de la Asociación Geológica Argentina 38, 405-411.

Varela, R., Dalla Salda, L.H., 1992. Geocronología Rb-Sr de metamorfitas y granitoides del tercio sur de la Sierra de Pie de Palo, San Juan, Argentina. Revista de la Asociación Geológica Argentina 47, 271-275.
Varela, R., López de Luchi, M., Cingolani, C., Dalla Salda, L., 1996. Geocronología de gneises y granitoides de la Sierra de Umango, La Rioja: Implicancias tectónicas. XIII Congreso Geológico Argentino Argentino y III Congreso de Exploración de Hidrocarburos, Actas, vol. 3, pp. 519-527.

Varela, R., Cingolani, C., Sato, A., Dalla Salda, L.H., Brito Neves, B.B., Basei, M.A.S., Siga Jr., O., Teixeira, W., 1997. Proterozoic and Paleozoic evolution of Atlantic area of the North-Patagonian Massif, Argentina. I South American Symposium on Isotope Geology (São Paolo, Brazil), Extended Abstracts, pp. 326-328.

Varela, R., Basei, M.A.S., Sato, A.M., Siga Jr., O., Cingolani, C.A., Sato, K., 1998. Edades isotópicas $\mathrm{Rb}-\mathrm{Sr}$ y U-Pb en rocas de Mina Gonzalito y Arroyo Salado: Macizo Norpatagónico Atlántico, Río Negro, Argentina. X Congreso Latinoamericano de Geología (Buenos Aires), Actas, vol. 1, pp. 71-76.

Varela, R., Basei, M.A.S., Brito Neves, B.B., Sato, A.M., Teixeira, W., Cingolani, C., Siga Jr., O., 1999. Isotopic study of igneous and metamorphic rocks of Comallo-Paso Flores, Río Negro, Argentina. II South American Symposium on Isotope Geology (Villa Carlos Paz, Argentina), Actas, pp. 148-151.

Vernon, R.H., Etheridge, M.A., Wall, V.J., 1988. Shape and microstructure of microgranitoid enclaves: indicators of magma mingling and flow. Lithos 22, 1-11.

von Gosen, W., Prozzi, C., 1998. Structural evolution of the Sierra de San Luis (Eastern Sierras Pampeanas, Argentina): Implications for the Proto-Andean Margin of Gondwana. In: Pankhurst, R.J., Rapela, C.W. (Eds.), The Proto-Andean Margin of Gondwana. Geological Society London, Special Publication, 142, 235-258.

Vujovich, G.I., 1998. Las metamorfitas del Cordón del Portillo, Cordillera Frontal, Argentina. X Congreso Latinoamericano de Geología y VI Congreso Nacional de Geología Económica (Buenos Aires), Actas, vol. 2, p. 411.

Vujovich, G., Kay, S.M., 1996. Evidencias geoquímicas del origen y ambiente geológico de las rocas metamórficas de composición máfica a intermedia de las Sierras Pampeanas Occidentales. XIII Congreso Geológico Argentino y III Congreso de Exploración de Hidrocarburos, Actas, vol. 5, pp. 273-291.

Vujovich, G.I., Kay, S.M., 1998. A Laurentian? Grenville-age oceanic arc/ back-arc terrane in the Sierra de Pie de Palo, Western Sierras Pampeanas, Argentina. In: Pankhurst, R.J., Rapela, C.W. (Eds.), The ProtoAndean Margin of Gondwana. Geological Society London, Special Publication, 142, 159-179.

Vujovich, G.I., Ramos, V.A., 1994. La faja de Angaco y su relación con las Sierras Pampeanas Occidentales. VII Congreso Geológico Chileno (Concepción, Chile), Actas, vol. 1, pp. 215-219.

Vujovich, G.I., Godeas, M., Marín, G., Pezzutti, N., 1996. El complejo magmático de la Sierra de la Huerta, provincia de San Juan. XIII Congreso Geológico Argentino y III Congreso de Exploración de Hidrocarburos, Actas, vol. 3, pp. 465-475.

Wareham, C.D., Pankhurst, R.J., Thomas, R.J., Storey, B.C., Grantham, G.H., Jacobs, J., Eglington, B.M., 1998. Pb, Nd, and Sr isotope mapping of Grenville-age crustal provinces in Rodinia. Journal of Geology 106, 647-659.

Weber, B., Köhler, H., 1999. Sm-Nd, Rb-Sr and U-Pb geochronology of a Grenville terrane in southern Mexico: Origin and geologic history of the Guichicovi complex. Precambrian Research 96, 245-262.

Wichmann, R., 1928. Reconocimiento geológico de la región del Nihuil con referencia especial al proyectado dique de embalse de las aguas del río Atuel (Provincia de Mendoza). Unpublished Report of theDirección Nacional de Geología y Minería, Buenos Aires. 